\title{
Disease-Suppressive Soils-Beyond Food Production: a Critical Review
}

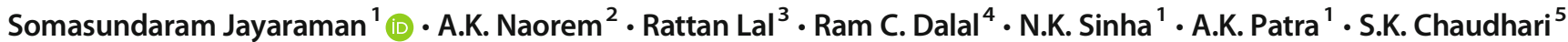

Received: 23 October 2020 / Accepted: 21 February 2021 / Published online: 12 March 2021

(C) Sociedad Chilena de la Ciencia del Suelo 2021

\begin{abstract}
In the pursuit of higher food production and economic growth and increasing population, we have often jeopardized natural resources such as soil, water, vegetation, and biodiversity at an alarming rate. In this process, wider adoption of intensive farming practices, namely changes in land use, imbalanced fertilizer application, minimum addition of organic residue/manure, and nonadoption of site-specific conservation measures, has led to declining in soil health and land degradation in an irreversible manner. In addition, increasing use of pesticides, coupled with soil and water pollution, has led the researchers to search for an environmentalfriendly and cost-effective alternatives to controlling soil-borne diseases that are difficult to control, and which significantly limit agricultural productivity. Since the 1960s, disease-suppressive soils (DSS) have been identified and studied around the world.

Soil disease suppression is the reduction in the incidence of soil-borne diseases even in the presence of a host plant and inoculum in the soil. The disease-suppressive capacity is mainly attributed to diverse microbial communities present in the soil that could act against soil-borne pathogens in multifaceted ways. The beneficial microorganisms employ some specific functions such as antibiosis, parasitism, competition for resources, and predation. However, there has been increasing evidence on the role of soil abiotic factors that largely influence the disease suppression. The intricate interactions of the soil, plant, and environmental components in a disease triangle make this process complex yet crucial to study to reduce disease incidence. Increasing resistance of the pathogen to presently available chemicals has led to the shift from culturable microbes to unexplored and unculturable microbes. Agricultural management practices such as tillage, fertilization, manures, irrigation, and amendment applications significantly alter the soil physicochemical environment and influence the growth and behaviour of antagonistic microbes. Plant factors such as age, type of crop, and root behaviour of the plant could stimulate or limit the diversity and structure of soil
\end{abstract}

\section{Highlights}

- In disease-suppressive soils (DSS), disease development is at the minimum level even in the presence of the soil-borne pathogen and the susceptible host plant.

- Disease suppression is mainly attributed to the intricate interactions between soil-plant-the microbiome-environmental factors.

- The microbial structure and community/composition in the rhizosphere of DSS differs remarkably from the conducive soils.

- Abiotic factors contribute to the sensitivity of disease suppressiveness in soil by limiting the strength and altering the direction of plant-soil feedbacks.

- Soil biodiversity strongly influences the disease suppressiveness through the trophic level and improving plant resistance.

- Farm management practices can greatly enhance the disease suppressiveness in soils.

Somasundaram Jayaraman

somajayaraman@gmail.com

1 ICAR-Indian Institute of Soil Science, Nabibagh, Berasia Road, Bhopal, Madhya Pradesh 462038, India

2 ICAR-Central Arid Zone Research Institute, Regional Research Station-Kukma, Bhuj, Gujarat 370105, India
3 Carbon Management Sequestration Center, The Ohio State University, 2021 Coffey Rd, Columbus, OH, USA

4 School of Agriculture and Food Sciences, The University of Queensland, St Lucia, QLD 4072, Australia

5 Indian Council of Agricultural Research, KAB-II, New Delhi, India 
microorganisms in the rhizosphere. Further, identification and in-depth of disease-suppressive soils could lead to the discovery of more beneficial microorganisms with novel anti-microbial and plant promoting traits. To date, several microbial species have been isolated and proposed as key contributors in disease suppression, but the complexities as well as the mechanisms of the microbial and abiotic interactions remain elusive for most of the disease-suppressive soils. Thus, this review critically explores disease-suppressive attributes in soils, mechanisms involved, and biotic and abiotic factors affecting DSS and also briefly reviewing soil microbiome for anti-microbial drugs, in fact, a consequence of DSS phenomenon.

Keywords Disease-suppressive soils $\cdot$ Microbiome $\cdot$ Soil-borne pathogens $\cdot$ Soil disease triangle $\cdot$ Metabiostasis $\cdot$ Predation $\cdot$ Parasitism $\cdot$ Antibiotics and drugs from the soil

\section{Introduction: the Need for Disease-Suppressive Soil}

The COVID-19 pandemic is testing the capability of human societies to survive under the harsh conditions of a global crisis. Despite these difficulties, we need to feed $\sim 10$ billion people by 2050, an increase of 2 billion people in the next 30 years with ever declining finite and fragile natural resources (Lal 2020). However, it is equally important to increase food production while maintaining the sustainability of the environment (Guerra et al. 2020; Lal 2020). Therefore, scientists across the globe are evaluating "soil" for greater opportunities and possibilities not only for food production but also for controlling diseases and infections (i.e. "drug from dirt", e.g. penicillin, streptomycin, rifamycin) (Ling et al. 2015).

Soil is a complex-dynamic ecosystem not only for providing food to all living organisms but also for hosting billions of microorganisms and microbiome (Guerra et al. 2020). In fact, a teaspoonful of productive soil contains between 100 million and 1 billion organisms alone (Anton 2017). Soil microorganisms, broadly classified into bacteria, archaea, fungi, algae, protozoa, and nematodes, are the primary drivers of essential ecological processes, services, and functions (Guerra et al. 2020).

In fact, modern agricultural systems are characterized by high input-based intensive cropping systems, continuous mono-cropping and limited crop rotations, and inappropriate management practices that have resulted in soil degradation with increasing soil acidity/salinization and low soil nutrient status, and also hampered ecological services and functions (Cao et al. 2004). In addition, plant diseases caused by soil-borne pathogens such as damping-off and Fusarium wilt, often cause substantial economic losses in major crops (Li 1995; Mandeel and Baker 1991). For example, soil-borne pathogens such as Fusarium pseudograminearum and Rhizoctonia solani could infect diverse crop species such as cereals, oilseed crops, and pasture plants and they are difficult to control due to their ability to persist in crop residues and litter for a longer period (Duveiller et al. 2007; Jeger et al. 1996; Neate 1994; Rovira et al. 1990). Chemical fumigation is mostly practised to reduce the inoculum level of these soil-borne pathogens (Duveiller et al. 2007; Jeger et al. 1996; Rovira et al. 1990). However, with the increasing awareness of sustainable agricultural practices, several fumigants have been restricted because of their negative impacts on the environment. For example, methyl bromide was banned in 2004 under the Montreal Protocol for its ability to deplete the ozone layer and increase global warming (Honaganahalli and Seiber 1996; Weller et al. 2006).

Soils team with a diverse group of microorganisms that possess the multifaceted plant growth-promoting traits and characteristics (Anton 2017; D'Costa et al. 2007). Studies on the interaction between soil microbiota and plants have attracted worldwide interest/attention because of the need for restoration and maintenance of biodiversity, which are priority issues in every conservation policy (Read 1998). "Soil microbiota" has been often studied for its critical roles in maintaining the integrity, functioning, and sustainability of the soil systems. Similarly, soil microbial community plays a crucial role in soil functioning and maintaining soil health, including the capacity to control diseases caused by soil-borne pathogens. A collective term of "superorganisms" can be applied to the plant system and its associated microbiomes that partly but crucially depend on the soil microbiome (a community of microbes in a particular environment) for specific functions and processes (Mendes et al. 2011). About 21\% of carbon (C) fixed through photosynthesis is exuded at the root surface (Marschner 1995) where the soil microbes feed on it, influencing their activity and diversity in the soil. Understanding this interaction between plants and soil microbes can help in the exploitation and recruitment of selective beneficial soil microorganisms by the plants to protect against infections from soilborne pathogens (Cook et al. 1995; Liu et al. 2020).

The current trend of "ecological intensification" of farms demands a promising crop protection/production with environmentally friendly practices such as maintaining and promoting disease-suppressive soils (Lin 2011; Smukler et al. 2010), which is one of the interesting characteristics possessed by the soil microbiome (Haas and Defago 2005; Weller et al. 2002). Disease-suppressive soil (DSS), as the name suggests, does not refer to the complete elimination of the soil-borne pathogens from the soil environment (Schlatter et al. 2017). It refers to those soils in which disease development is at the minimum level even in the presence of the soil-borne pathogen and the susceptible host plant (Mazzola 2007; Siegel- 
Hertz et al. 2018). Although it is of prime importance to understand the functioning of the DSS (Kinkel et al. 2011), relatively few soils with suppressive properties have been described in the global literature to date (Kyselková et al. 2012). Disease suppressiveness not only refers to the healthy soils with a stable soil microbial community but also consists of advantageous physical and chemical soil properties (Expósito et al. 2017) that enhance crop protection. Soil disease suppression can be regarded as the soil biological property conferred by the microbial community (microbiome) because sterilization of DSS destroys the disease controlling capacity of the suppressive soils and, in addition, the transfer of disease suppressiveness could be possible when conducive soil receives an amount of suppressive soil (Stutz et al. 1986). The postulation of Cook et al. (1995) and the experimental support provided by Liu et al. (2020) that plant species tend to develop their defence strategy against soil-borne diseases/ pathogen through selective stimulation and support of antagonistic microorganisms also, indicates the potential of DSS in disease control (Hadar and Papadopoulou 2012; Mousa and Raizada 2016; Schlatter et al. 2017).

Among the soil-borne pathogens, fungi and Oomycetes are one of the major pathogens which limit the productivity of the agroecosystems and are relatively difficult to control with the introduction of resistant host cultivars and use of synthetic fungicides (Jambhulkar et al. 2015). Few soil-borne diseases, for example, Aphanomyces euteiches Dress. that causes root rot of pea (Pisum sativum L.), are difficult to control with fungicides or developing plant resistance (Persson and Olsson 2000). The only practical method to reduce the losses is to completely avoid infection of the crops with pathogens (Persson and Olsson 2000). Therefore, in such cases, developing soil-related disease suppressiveness could potentially work in reducing the loss of productivity due to the soilborne pathogens (Persson and Olsson 2000). Therefore, the development of DSS could be one of the effective examples in which the indigenous soil microbiota effectively protects the host plant against the infections from soil-borne pathogens (Weller et al. 2002). Deciphering the rhizosphere microbiome to screen and identify those beneficial microbes that contribute to disease suppression is the first step in unravelling the direct and indirect mechanisms of DSS (Weller et al. 2002).

The DSS has been observed for several soil-borne pathogens such as Streptomyces scabies (Menzies 1959), Pythium splendens (Kao et al. 1983), Pythium ultimum (Martin et al. 1986), Thielaviopsis basicola (Stutz et al. 1986), Heterodera avenae (Kerry 1988), Phytophthora cinnamomi (Ko et al. 1989), Criconemella xenoplax (Kluepfel et al. 1993), Phytophthora infestans (Andrivon 1994), Fusarium oxysporum (Alabouvette et al. 1993; Siegel-Hertz et al. 2018), Rhizoctonia solani (Wiseman et al. 1996), Meloidogyne spp. (WeibelzahlFulton et al. 1996), Gaeumannomyces graminis var. tritici (Hornby 1998), H. schachtii (Westphal et al. 1999), Ralstonia solanacearum (Shiomi et al. 1999), Aphanomyces euteiches (Persson et al. 1999), and Plasmodiophora brassicae (Murakami et al. 2000).

The so-called disease-suppressive soils have the ability to suppress the various plant pathogens by improving the plant health, induce natural plant defence, produce antibiotics, compete against pathogens, modulate plant immune system, or hyperparasite the pathogen (Liu et al. 2020; Mousa and Raizada 2016; Schlatter et al. 2017). These DSS have been identified for almost 60 years before (Menzies 1959); however, recent advances in next-generation sequencing methods have open the new arena in the understanding of DSS (Mendes et al. 2011). Moreover, comprehensive information on DSS is lacking. Thus, an attempt has been made in this review to understand different aspects of DSS such as types of disease suppressiveness, mechanisms, biotic and abiotic factors on DSS, method of study, and soil attributes on disease suppressiveness. This article also deliberates DSS under different management practices and indicates undiscovered soil microbiome for antibiotics and drugs and complexities in understanding disease suppressiveness.

\section{Types of Soil-Related Disease Suppression}

The basic reason for the high incidence of soil-borne diseases in croplands is the deterioration of the soil micro-ecological environment that often disrupts the soil microbial community balance (Mazzola 2007). Therefore, attempts have been made to differentiate the microbial community structure of DSS from those of disease-conducive soil (DCS) (Garbeva et al. 2004; Kinkel et al. 2011). Maintaining a dynamic microbial balance between species, high soil microbial biomass, and high microbial diversity are key factors which facilitate the development of DSS (Cook and Baker 1983; Schlatter et al. 2017; Wellar et al. 2002; Zak et al. 2003). High microbial diversity in the soil allows fewer pathogens to survive, and may also prevent the invasion of exogenous pathogens (Benizri et al. 2005). Several soil microorganisms confer benefits in nutrient acquisition (Berendsen et al. 2012; Chaparro et al. 2012) and protect host plants by preventing colonization from soil-borne pathogens (Cook and Baker 1983; Hadar and Papadopoulou 2012; Latz et al. 2012; Schlatter et al. 2017; Wellar et al. 2002).

There are two distinct types of disease suppressiveness in soil: general and specific mechanisms. General suppression mechanism (GSM) refers to the widespread but limited potential of the soil in suppressing the disease-causing activity of soilborne pathogens (Cook et al. 1983; Cook et al. 1987). It is also referred to as non-specific antagonism (Rovira et al. 1981) or biological buffering (Huber et al. 1970). The GSM category refers to the disease suppression through the competition between the resident soil microbes and pathogens for a common resource such as nutrients and/or space and the release of 
antibiotic compounds and toxins from an active soil microbial community that hampers the growth and development of the specific pathogen (Hadar and Papadopoulou 2012). On the other hand, specific suppression mechanism (SSM) is another type of disease suppression but superimposed over the main concept of GSM (Gerlagh 1968). The SSM refers to the effects of an individual or specific groups of soil microorganisms (or during specific stages of pathogen life cycle) on disease suppression (Cook et al. 1976). The distinctive characteristic of SSM is its transferability factor (Andrade et al. 1994); i.e. it can be transferred from suppressive soil to a conducive soil. The specific mechanism includes parasitism and predation of the pathogens by the soil-dwelling microbes. However, in general, the mechanism of soil suppression includes antibiosis, competition, parasitism, and predation (Chandrashekara et al. 2012). They have their activity in a blend of "general" and "specific" suppression.

General suppression is the capacity of soils to suppress the growth and activity of soil-borne pathogens to a certain level due to the combined competitive and antagonistic activity of the total soil microbiome fighting with the pathogens (Cook 2014; Weller et al. 2002). Though some argue for limiting the use of the term disease suppressiveness to situations involving a clear biological component, there is plentiful evidence for the role of both biotic and abiotic elements of the soil having a role in disease suppression (Mousa and Raizada 2016; Scholthof 2007; Yin et al. 2013). Chemical and physical attributes of soil, including $\mathrm{pH}$, soil organic matter (SOM), and clay content, can operate in the suppression of plant diseases directly or indirectly through their impact on soil microbial activity (Sullivan 2001). These soil attributes are largely influenced under different management practices, and thereby control the microbial population and diversity in soil rhizosphere (Peters et al. 2003).

Long-standing type of disease suppression occurs in soils with specific disease suppression, in which the disease suppression is naturally associated with the soil without the presence of plants, although its origins are unknown (Weller et al. 2002). The Fusarium wilt suppressive soils from Chateaurenard region of France are one such example of long-standing disease suppression (Alabouvette 1986). On the other hand, "induced" type of specific disease suppression is associated with sustainance of disease suppression through crop monoculture or inoculation of the soil with pathogens or by growing susceptible crops (Weller 2002). A prominent example of "induced" specific suppression is decline of take-all disease through wheat monoculture (Weller 2002).

\section{The Disease Triangle Model: Complex yet Intriguing}

As the soil microbes and the pathogens share a common space in the rhizosphere, their interactions during pre- and postplanting have a great influence on plant productivity (Penton et al. 2014). The whole disease suppression concept can be visualized with a disease triangle concept that consists of three major determinants: host plant, soil-borne pathogen, and environmental factors (Fig. 1) (Scholthof 2007). Since plants are the main providers of soil $\mathrm{C}$ and energy sources, plant diversity affects the composition and structure of microbial communities (Scholthof 2007). The physical and chemical properties of soil such as $\mathrm{pH}$, electrical conductivity, soil nutrients, and soil organic carbon (SOC) also determine the microbial activities as soil provides the optimum habitat for the growth and development of the soil microbes (Hadar and Papadopoulou 2012). In addition to these, crop management practices such as tillage, fertilization, weeding, and irrigation manipulate the soil environment and affect the population of soil microbiota (Fig. 2). It is nearly an impossible task to study the roles of these factors independently in disease suppression, and researchers need to address them simultaneously (Yin et al. 2013). Understanding the disease triangle model (i.e. a model based on the interactions between the host plant, pathogen, and the environment conducive for disease development) is one of the key steps in studying the complex system of the DSS (Scholthof 2007). Diseases are developed when all the components of this model are in favourable conditions for the pathogen. The "environment" component needs to be manipulated and specifically tailored to develop DSS or reduce the conduciveness of disease development even in the presence of the pathogen and the host (Hadar and Papadopoulou 2012). Until and unless soil properties are completely modified or pathogens are mutated, the persistence period of disease suppression is quite long even with the repeated introduction of the pathogen in soil (Cook et al. 1995).

Commonly available amendments such as vermicompost, rice straw, animal manure, and green waste are potential amendments which have disease-suppressive qualities through their influence on soil microbial communities (Liu et al. 2007). However, despite showing satisfactory properties of the biocontrol amended soils in either laboratory or controlled conditions, it is a major challenge to achieve the same results under field conditions (Bonanomi et al. 2010; Termorshuizen et al. 2006). Such a differential response is attributed to the complex and specific interactions between these components in the disease triangle model, and better mixing of the bio-inoculant enriched compost with the soil in controlled conditions than in the fields.

Sullivan (2001) also reported that the degree of suppressiveness is linked to soil physical conditions, fertility level, biodiversity and populations of soil organisms, and soil management practices. For example, use of manure application modifies soil physical, chemical, and biological parameters that directly affect crop infection and the survival of the pathogen. Scheuerell et al. (2005) found that Pythium sp. suppression was linked to volatilization of ammonia from manure amendments. Similarly, Conn and Lazarovits (1999) 
Fig. 1 Concept of soil disease triangle with main components and their respective factors (source: author/developed by authors)

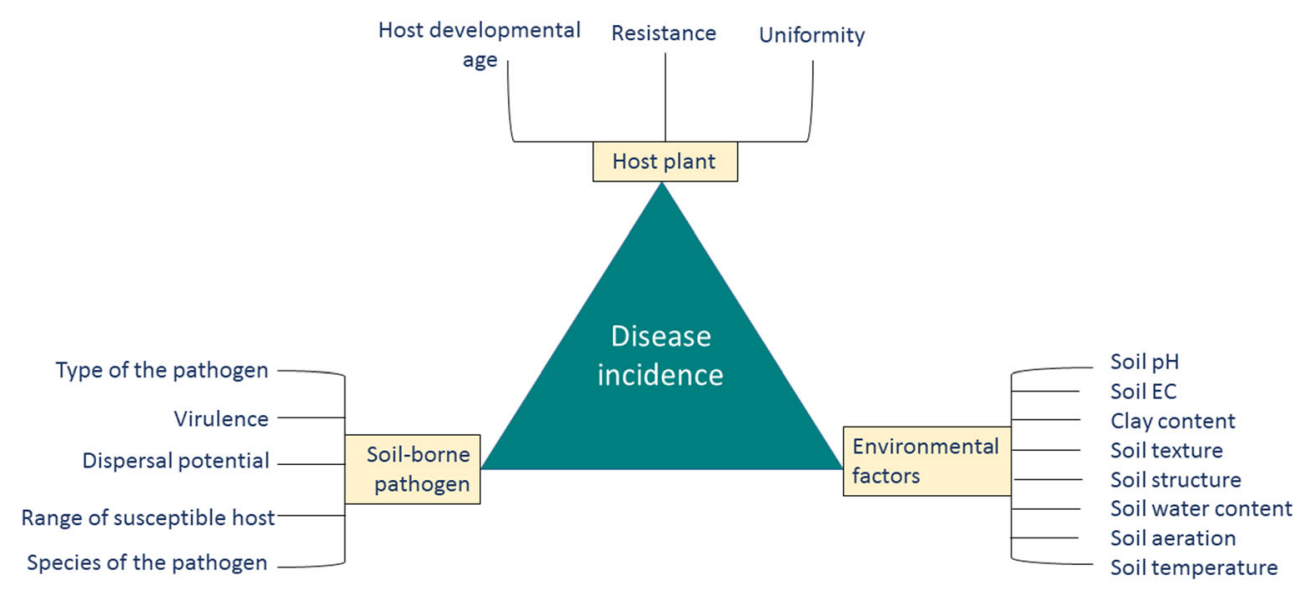

reported that the application of liquid swine manure reduced the occurrence of wilt, as well as a common scab in potato fields. It also lowered the number of plant-parasitic nematodes for a period of 3 years following a single-use. A significant reduction in root disease of the red stele strawberry was also observed in fields treated with steer/poultry and dairy manure compost, comparative to control (Millner et al. 2004).

\section{Biotic Contributors to Disease-Suppressive Soils}

\subsection{Soil Bacterial and Archaeal Community}

The composition of the microbial community is one of the major factors in the mechanism of disease suppression (Shi et al. 2019). In microarray analysis, higher signals in suppressive soil could be observed from non-pathogenic Streptomyces (Actinobacteria), Bradyrhizobium, Burkholderia (Brader et al. 2014; Kyselková et al. 2012), and Nitrospira (Uroz et al. 2016) whereas the conducive soil exhibits higher signals from Acidobacteria, Pseudomonas, Agrobacterium, and Janithobacterium (Proteobacteria) (Ditt et al. 2002; Loudon et al. 2014). Actinobacteria (multicellular bacteria) are known for their inherent ability to produce a large number of bioactive secondary metabolites such as $2,4-$ diacetylphloroglucinol (DAPG) that can inhibit the growth of the soil-borne pathogens (Claessen et al. 2014). Similarly, the archeal community is also neglected in biocontrol and disease suppressiveness even though it is also a part of the rhizosphere microbiome (Mendes et al. 2011; Taffner et al. 2018). Kopecky et al. (2019) differentiated a suppressive soil from a conducive soil by lower quantities of actinobacteria and a specific composition in archaea and micro-eukaryotes. In a PhyloChip-based metagenomics study of the rhizosphere microbiome, Mendes et al. (2011) detected more diseasesuppressive characteristics in Proteobacteria, Firmicutes, and Actinobacteria. Other pathogens suppressing members often detected are Xylariaceae, Lactobacillaceae, and Bacillus (Penton et al. 2014; Wu et al. 2008), Enterobacter
Fig. 2 The interplay of the soil inherent factors and environmental changes in the development of diseasesuppressive soils (source: author/ developed from a number of literature sources)

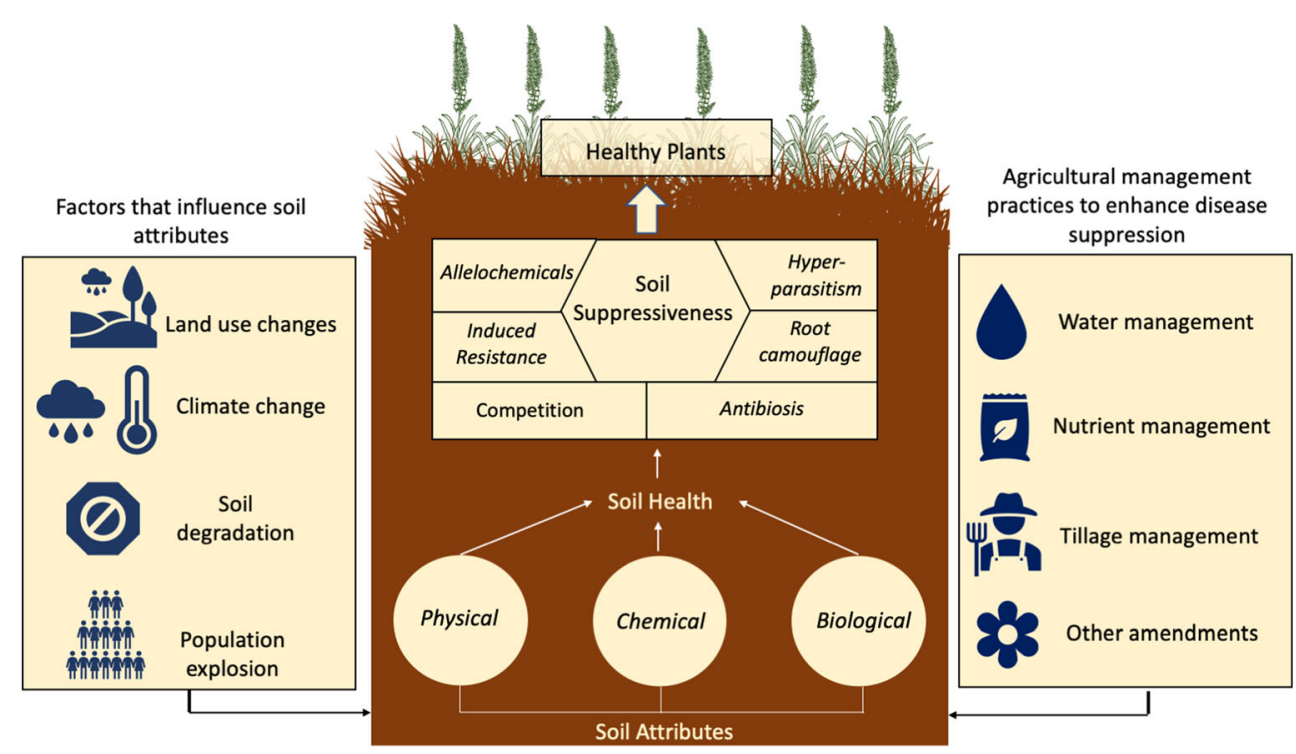


spp., Flavobacterium aluminium Harrison, Pseudomonas spp., Streptomyces spp., Penicillium spp., and Trichoderma spp. (Hoitink et al. 1997). On the other hand, Durán et al. (2018) suggested that the suppression of Gaeumannomyces graminis var. tritici (the fungal pathogen responsible for development of take-all disease in wheat) is mostly mediated through bacterial endophytes rather than rhizospheric microoorganisms and emphasized that mere reduction of pathogen biomass is not key factor in disease suppression.

\subsection{Soil Fungal Community}

Most of the soil suppressive assessment studies are focused on soil bacteria (Shi et al. 2019). Although fungi and microeukaryotes are closely associated with disease suppressiveness and are crucial for crop protection, most of them are comparatively neglected (Gao et al. 2019). Microfauna and mesofauna can feed on pathogens, help in nutrient cycling/ turnover, and maintain species diversity by consuming dominant bacterial taxa (Zahn et al. 2016). Soils with high disease suppressiveness are also associated with higher fungal diversity (Gupta et al. 2010). As there exists a large diversity of uncultured fungi in the soil, culture-independent approaches must be developed to describe the fungal community and screen the fungi with high disease suppressiveness ( $\mathrm{Xu}$ et al. 2012a). For example, Penton et al. (2014) revealed the fungal composition differences between suppressive and nonsuppressive soils using culture-independent terminal restriction fragment length polymorphism (T-RFLP) method.

Arbuscular mycorrhizal (AM) fungi could help in disease suppression in several ways ( $\mathrm{Li}$ et al. 2007). The AM plants could recruit more pathogen-antagonistic actinomycetes than the non-mycorrhizal plants (Secilia and Bagyaraj 1987). AM fungi do not compete with other growth-promoting rhizobacteria; rather they interact for the mutual establishment to increase plant health (Barea et al. 1996). AM fungi are often known to increase the nutritional status of the host plant and help indirectly in the suppression of plant diseases. AM increases available phosphorus and is found to increase tolerance of the plants to pathogen damage ( $\mathrm{Li}$ et al. 2007). Other non-nutritional mechanisms of AM fungi are changes in exudation patterns, activation of plant defence systems and increased lignifications of cell walls, and competition for space for colonization and infection sites (Cardoso and Kuyper 2006). AM fungi also release a variety of antibiotics and other toxins that act against pathogenic organisms (Meyer and Linderman 1986). The feeding preferences of the biocontrol agent are one of the major determinants in developing specific rhizosphere microbiome (Gao et al. 2019). The interactions between different trophic levels (an organism's position it occupies in a food web) can modify the nutrient cycling and influence soil nutrient status and plant nutrition (Abdallah et al. 2019) that further affects the soil suppressiveness (Krištůfek et al. 2000).

\section{Is Disease Suppression Abiotic in Nature?}

\subsection{Temperature}

Soil physical and chemical properties are also useful indicators in predicting the suppressive level of the soil (Löbmann et al. 2016) (Fig. 3). Soil abiotic factors could influence the disease suppression in soil by limiting the strength and altering the direction of plant-soil feedbacks (Mavrodi et al. 2012). The sensitivity of the disease suppressiveness to temperature depicts the contribution of several temperature-sensitive and/ or resistant microbes in disease suppression. Mendes et al. (2011) observed the reduction of pathogen suppressiveness at $50{ }^{\circ} \mathrm{C}$ and complete destruction of soil disease suppressiveness at $80^{\circ} \mathrm{C}$, suggesting that total suppressiveness could have been controlled by a mixed group of biocontrol agents: a group of temperature-sensitive Gram-negative bacteria that worked till the temperature of the soil reached $50{ }^{\circ} \mathrm{C}$ and another group of less sensitive spore-forming micro-organisms that are killed beyond $80^{\circ} \mathrm{C}$. This temperature sensitivity clearly indicates the contribution of more complex microbial communities in the suppression of diseases in soil (Yin et al. 2013).

\subsection{Clay Content and Cation Exchange Capacity}

Abiotic factors such as high clay content in soil and high cation exchange capacity (CEC) can suppress the infection rate of Pythium ultimum (Martin and Hancock 1986). Several investigations have revealed the impact of clay minerals in disease suppression (Stotzky and Martin 1963; Stotzky and Post 1967; Stutz et al. 1989). Presence of smectite type of clay has been shown to enhance bacterial respiration and increase disease suppression (Amir and Alabouvette 1993; Rosenzweig and Stotzky 1979; Stotzky 1966a, 1966b, 1986; Stotzky and Rem 1966). Persson and Olsson (2000) found a strong positive relationship between disease suppression of Aphanomyces root rot and ratio of vermiculitesmectite to illite-kaolinite ratio, increase in clay content, soil calcium content and soil $\mathrm{pH}$. Smectite and vermiculite have high CEC, and the resulting high buffering capacity could relate to the abundance of charged components such as organic matter and thus have higher suppressiveness to diseases such as Fusarium wilt (Fusarium oxysporum $f$. sp. cubense (Foc)) of banana (Stotzky and Martin 1963). Few corpora of evidence presented contrasting results where smectite- and illite-rich soils were conducive to diseases, and vermiculite rich soils were suppressive to black rot (Thielaviopsis basicola Berk \& Broome) of tobacco (Stutz et al. 1989). Therefore, it 


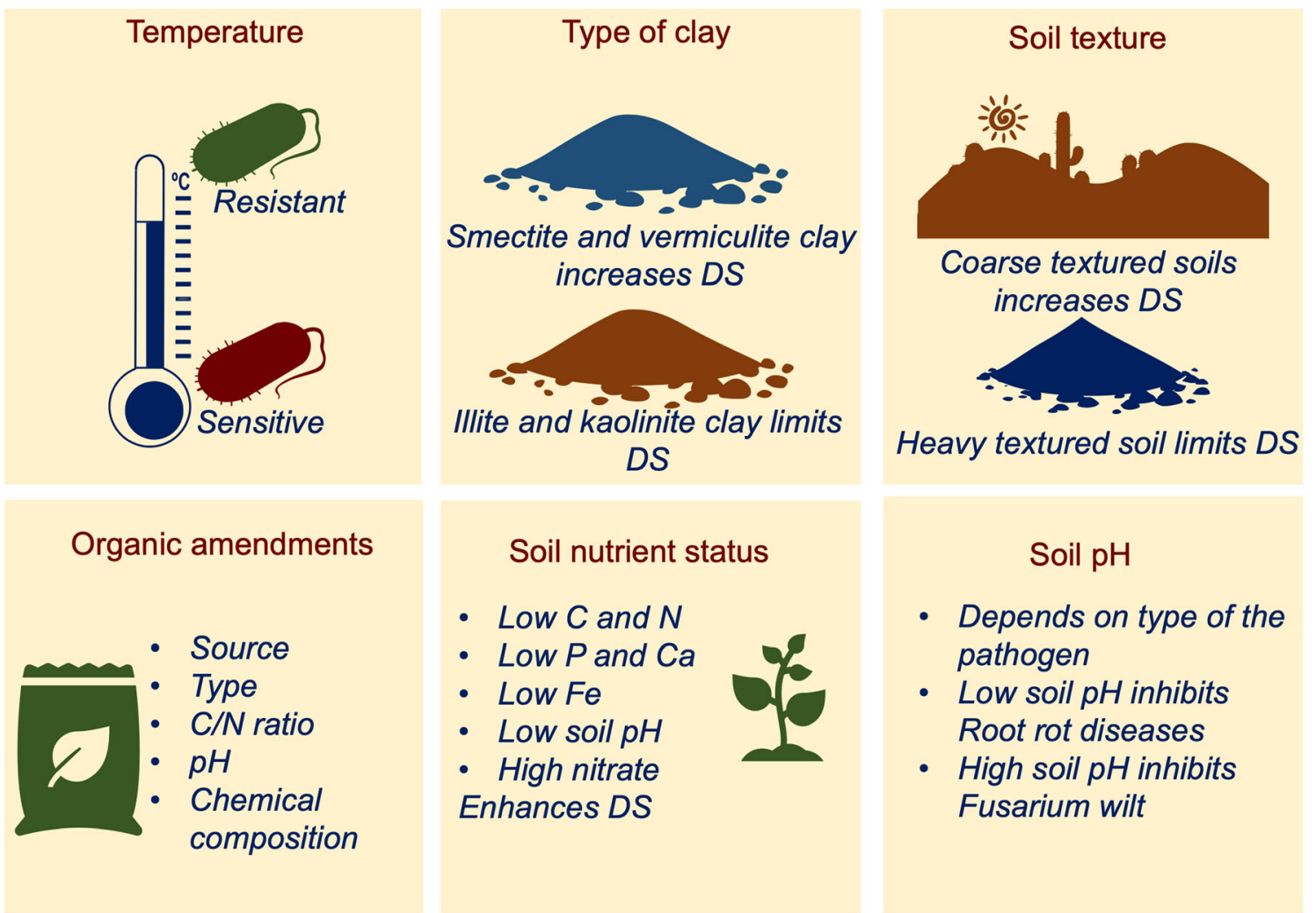

Fig. 3 Effects of soil abiotic factors on disease suppressiveness (DS) (source: author/compiled from a number of literature sources)

appears that it is not the specific type of clay minerals that affects the disease suppressiveness; rather it is the ratio of clay minerals with high and low CEC that determines the disease suppressiveness of a particular soil (Persson and Olsson 2000) (Fig. 3). However, the sole presence of clay minerals with high surface area and CEC do not favour disease suppression because sterilization or pasteurization of vermiculite rich soils could not impede the infection of soil-borne pathogens such as Thielaviopsis basicola in tobacco (Ramette et al. 2006).

\subsection{Soil Texture}

Another group of study addressed the importance of soil texture in disease suppression of some pathogens (Amir and Alabouvette 1993). The infection of a host plant depends on the high water content of soil (Papavizas and Ayers 1974). Therefore, coarse-textured soils showed higher disease suppression due to their better water drainage system than heavytextured soils (Westerlund et al. 1978) (Fig. 3).

\subsection{Quality of Organic Amendments}

The high efficiency of organic matter in disease suppression may also be attributed to its high CEC (Brady 1984). The C/N ratio of the organic compounds added to the soil also affects the balance between microbial communities and can have cascading effects on the soil organisms in high trophic level
(Stirling 2014). Low C/N ratio also favours Fusarium wilt, even in the presence of bicontrol agents (Hoitink et al. 1993).

\subsection{Soil Nutrient Status}

Soil suppressiveness frequently occurs in soils with highnutrient conditions (Tamm et al. 2010). Nutrient depletion in the soil makes the plants unhealthy and more susceptible to pathogens (Fig. 3). Therefore, maintaining optimum nutrient balance in the soil is crucial for biological disease suppression (Ghorbani et al. 2008). As labile $\mathrm{C}$ is the small but important component of the total soil $\mathrm{C}$ that is readily available to soil microorganisms (Haynes 2005), labile $\mathrm{C}$ fraction and their characteristics have been strongly correlated to soil disease suppressiveness (Cao et al. 2016; van Overbeek et al. 2012) and, therefore, it can be a novel soil indicator for soil suppressiveness and can be linked to several other diseasesuppressive indicators. Similarly, high soil nitrogen (N) and high ammonia:nitrate ratio favours the abundance of Fusarium wilt disease (Huber and Thompson 2007). Therefore, nitraterich composts are recommended in control of Fusarium wilt diseases in crops. Among the abiotic factors, lower soil N, C, phosphorus $(\mathrm{P})$, calcium $(\mathrm{Ca})$, iron $(\mathrm{Fe})$, and soil $\mathrm{pH}$ have been found to be positively correlated with suppressiveness of potato scab (caused by Streptomyces spp.) disease (Kopecky et al. 2019). The relation of disease suppressiveness with lower available $\mathrm{N}$ status is attributed to the dominance of 
ammonia-oxidizing archaea, suggesting that $\mathrm{N}$ is more intensively recycled in suppressive soil than that in conducive soil (Gao et al. 2019). A negative correlation could be observed between disease severity and plant magnesium $(\mathrm{Mg})$ content (Lazarovits et al. 2007), and exchangeable $\mathrm{Ca}, \mathrm{Mg}$, and $\mathrm{K}$ (Lacey et al. 2001). The antagonistic or compatible interactions between nutrients also affect the nutrient-related disease suppression (Krištůfek et al. 2015).

\subsection{Soil pH}

Root rot diseases caused by Phytophthora are generally inhibited by lower soil pH (Jambhulkar et al. 2015) (Fig. 3). Low soil $\mathrm{pH}$ restricts sporangium formation, zoospore release, and motility of the pathogen. Therefore, low $\mathrm{pH}$ sphagnum mosses are applied to reduce the populations of Phytophthora and Pythium spp. (Jambhulkar et al. 2015). On the other hand, high soil $\mathrm{pH}$ restricts Fusarium wilt occurrence by reducing the availability of soil nutrients to the pathogen (Jones et al. 1991). The effect of soil properties on developing biocontrol soil microbiome may differ from one microbe to another. For example, soil $\mathrm{pH}$ has stronger effects on soil bacterial diversity than the fungal diversity (Rousk et al. 2010). Abiotic factors along with the biological components are involved together in disease suppression. For example, in the disease suppression of damping-off in cucumber (Cucumis sativus L.), both the combination of increased microbial activity and high soil Ca level was important to suppression (Kao and Ko 1986).

\section{An Approach to Evaluate a Disease-Suppressive Soil}

Developing and studying a disease-suppressive soil consists of understanding the microbiological basis of disease suppressiveness and identification of the roles of each microbial group in disease suppression (Weller et al. 2002). The first step is to check whether the disease-suppressive soil is microbiological in nature or not, and it can be carried out through pasteurization (moist heat, $60^{\circ} \mathrm{C}$ for $30 \mathrm{~min}$ ), soil fumigation, steaming, autoclaving, gamma radiation, or using selective biocides (Kao et al. 1983; Kluepfel et al. 1993; Rouxel et al. 1977; Shiomi et al. 1999; Weibelzahl-Fulton et al. 1996; Wiseman et al. 1996). The effects of these treatments may vary according to the type of suppression. Autoclaving and gamma radiation can eliminate both the general and specific suppression (Weller et al. 2002). On the other hand, soil fumigation could only reduce general suppression (Cook et al. 1976). The steps usually followed in studying the disease-suppressive soil are shown in the flowchart (Fig. 4).

\section{Mechanisms of Soil-Related Disease Suppression}

Maintaining high functional soil microbial biodiversity increases ecosystem resilience making the soil less vulnerable to short-term changes in the environment (Allison and Martiny 2008). Therefore, soil biodiversity can significantly contribute to disease suppressiveness through direct (i.e. supporting higher trophic level organisms that feed on pathogens) and indirect mode (i.e. improving the plant health and resistance) (Reeleder 2003; Stirling 2014). In general, the biological mechanisms through which the disease-suppressive soils control the disease development are as follows (Hoitink and Boehm 1999) (Fig. 5):

(a) Parasitism against pathogens by a group of beneficial microbes/microbial communities

(b) Production of metabolites, toxins, and antibiotics (Adesina et al. 2007; Garbeva et al. 2006)

(c) Competition for nutrients/resources/substrates

(d) Activation of disease-resistant genes in the host plant by the beneficial microbes

(e) Improved plant nutrition and soil health

Disease suppressiveness could be attributed to combinations of antagonistic micro-organisms which support each other forming a microbial consortium and acting on a specific soil-borne pathogen. For example, the combined actions of mutually compatible non-pathogenic Fusarium strains and fluorescent Pseudomonas could stimulate the soil suppressiveness in Chateaurenard soil in France (Lemanceau and Alabouvette 1991). The relative abundance of disease-suppressive functional genes can be assessed by targeting the prnD gene (Peralta et al. 2018). The prn $\mathrm{D}$ gene is responsible for producing antifungal compounds such as pyrrolnitrin (PRN) (Garbeva et al. 2004).

The natural development of disease-suppressive soil is a very slow process and can take several years during which outbreaks of disease incidence may be at the higher rate (Cha et al. 2016; Garbeva et al. 2004; Mendes et al. 2011; Weller et al. 2002). The process of natural disease suppression is a time-consuming phenomenon as soil microorganisms need to stabilize the soil with a multitude of physical and chemical processes so that diverse soil microorganisms are likely to dominate (Wall et al. 2012). Farmers might be reluctant to promote naturally occurring disease suppression. Therefore, the speed of developing DSS can be accelerated with the artificial management strategies in mainstream practice (Mendes et al. 2011) 
Fig. 4 Flowchart depicting the general process to study specific disease-suppressive soils (authors modified step-wise protocol in the form of the flow chart from Weller et al. 2002)

\begin{tabular}{|c|c|}
\hline \multirow{8}{*}{ 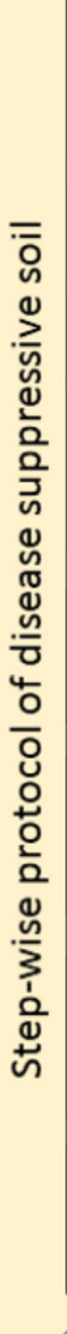 } & $\begin{array}{l}\text { Elimination of specific microbial groups by selective heat } \\
\text { treatment or biocides }\end{array}$ \\
\hline & Isolation of microbial groups \\
\hline & Evaluation of the suppressiveness of microbial groups \\
\hline & $\begin{array}{l}\text { Introduction of representatives of microbial groups into } \\
\text { conducive soils }\end{array}$ \\
\hline & $\begin{array}{l}\text { Transfer of suppressiveness to conducive soils with } 0.1- \\
10 \% \text { suppressive soil }\end{array}$ \\
\hline & $\begin{array}{l}\text { Phenotypic characterization of microbial groups that confer } \\
\text { suppressiveness }\end{array}$ \\
\hline & $\begin{array}{l}\text { Analysis of genotypic diversity among and within } \\
\text { functional groups }\end{array}$ \\
\hline & $\begin{array}{l}\text { Elucidation of mechanism(s) by which micro- organism(s) } \\
\text { suppress disease }\end{array}$ \\
\hline
\end{tabular}

\subsection{Bacterial Attachment to Pathogens}

Attachment of beneficial soil microbes to the cuticles of parasitic nematodes, such as root-knot nematode (Meloidogyne hapla), is an interesting mode of action for disease suppression (Adam et al. 2014). There is increasing evidence of microbial attachment of antagonists to the cuticles and surface coats of disease-causing parasites (Davies et al. 2011). The highly glycosylated mucins of the surface coat of the nematode play an important role in microbial specificity (Davies et al. 2011). The form of bacterial adhesion changes with the modification of the complex carbohydrates of the nematode surface coat (Davies et al., 2008; Gravato-Nobre et al. 2011). A fungus of the genus Rhizophydium was reported attaching to the surface coat of Criconemoides sp. (Esser et al. 1983). A fungus related to Cylindrocarpon olidum could be found on the surface coat of M. hapla and reduce the number of galls in tomato roots (Freitas et al. 1995) or inhibit the egg hatch of the nematode through the production of metabolites (Meyer et al. 2004).

\subsection{Microbiostasis}

Manipulating the soil nutrient content to provide nutrient stress to the soil microbial community and to repress the spore germination and growth of the pathogen is termed as "microbiostasis" or "fungistasis" (Jambhulkar et al. 2015). It results from the loss of energy of the propagule and finally die due to the nutrient stress (Bonanomi et al. 2007) For example, insufficient nutrients in soil restrict the germination of fungal conidia and the chlamydospores (thick-walled spores produced asexually from mycial cells) of Fusarium spp. (Jambhulkar et al. 2015). 
Fig. 5 Possible mechanisms of disease-suppressive soils - a close view (source: author)

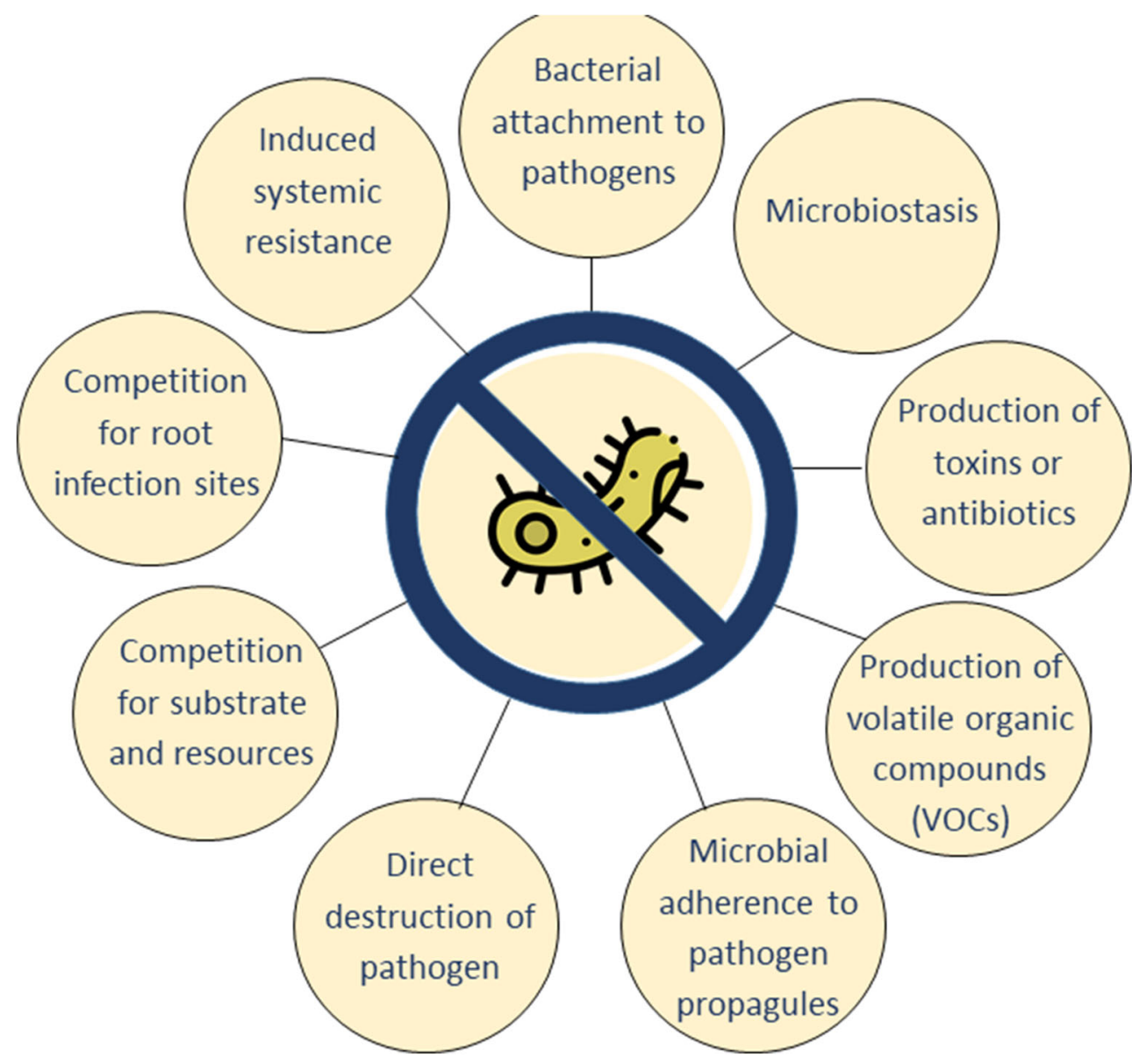

\subsection{Production of Toxins or Antibiotics}

Common scab of potatoes is caused by a soil-borne pathogen Streptomyces that releases phytotoxins (Thaxtomin) (Lorang et al. 1995). Disease control of common scab of potato is carried out through biological interactions (antibiotic production and enzyme activities) between beneficial microbiota and the pathogens (Rosenzweig et al. 2012). Another example of antibiosis is bacterial production of pyrrolnitrin (PRN) and 2,4-diacetylphloro-glucinol (DAPG) that are known to suppress the fungal pathogens in the soil (Haas and Defago 2005). Presence of 2,4diacetylphloroglucinol (DAPG)-producing bacteria such as Burkholderia cepacia and Peanibacillus azotofixans largely depends on the age of the host plant (Picard et al. 2000). In maize (Zea mays), the abundance of DAPG producers was relatively low in the first stage of plant growth than at the advanced stage (Di Cello et al. 1997). Other studies confirmed that young and immature roots recruit more r-strategists (microbes typically living in unstable environments) (De Leij et al. 1993) and mature roots stimulate more abundance of k-strategists (microbes that occupy more stable environments) (De Leij et al. 1995; Nacamulli et al. 1997). Therefore, disease suppression depends not only on plant type but also on phenological stage of plant development.

\subsection{Production of Volatile Organic Compounds}

The genus Streptomyces also accounts for $80 \%$ of the currently available antibiotics (Watve et al., 2001). Streptomyces produces several volatile organic compounds (VOCs) that reduce the severity of plant diseases by causing morphological abnormalities in different fungal pathogens (Boukaew et al. 2013; Wang et al. 2013). Members of the genus Streptomyces that are found antagonistic to $R$. solani could produce more than 10,000 secondary metabolites including VOCs (van Wezel et al. 2009). The chemical composition of VOCs is highly diverse, complex, and unique to each microorganism (Schulz and Dickschat 2007). These microbial VOCs can exhibit versatile functions as they can inhibit pathogen growth, enhance plant growth, and stimulate plant resistance (Bailly and Weisskopf 2012; Schmidt et al. 2015). The chemical composition of VOCs is the main factor for their specificity in their target pathogens. For example, Pseudomonas can produce VOCs such as cyclohexanal, decanal, 2-ethyl 1-hexanol, nonanal, benzothiazole, and dimethyl trisulfide that can inhibit the fungal growth and germination of Sclerotinia sclerotiorum 
(Fernando et al. 2005). Streptomyces can produce butanone (methyl vinyl ketone) and dimethyl disulphide that inhibit the spore germination of Cladosporium cladosporioides (Wang et al. 2013). Streptomyces albus produces anisole that acts against $S$. sclerotiorum and $F$. oxysporum (Wu et al. 2015). These VOCs also display their role in plant growth promotion such as the production of indole, 1- hexanol, pentadecane, 13tetradecadien-1-ol, 2-butanone, and 2-methyl-n-1-tridecene and indirectly influence the disease suppression (Park et al. 2015).

In addition, VOCs also function as signalling molecules in intraspecific interactions and indirectly help in disease suppression but its primary modes of action are not known (Schmidt et al. 2015). Thus, further studies must be conducted to provide a more conclusive proof of the role of VOCs in disease suppression using specific soil bioassays where VOC producers and the pathogen are physically separated (Cordovez et al. 2015).

\subsection{Adherence and Microbial Colonization of Pathogen Propagules}

The propagules of soil-borne pathogens are typically colonized by higher populations of bacteria, fungi, and protozoa in suppressive soils (Toyota and Kimura 1993). The colonized pathogen spores are difficult to germinate and lyse readily than non-colonized spores (Lockwood 1990). For example, bacterial colonization of Cochliobolus spp. (causal organism of root rots of grasses) can decrease the virulence of the pathogen (Fradkin and Patrick 1985).

\subsection{Direct Destruction of Pathogen Propagules}

The antagonists stimulate lysis of pathogens, degradation of chlamydospores, conidia and zoospores (Jambhulkar et al. 2015). For example, Trichoderma spp. (biocontrol agent) act on Phytophthora spp. (pathogen) by stimulating hyphal lysis of the pathogen (Costa et al. 2000).

\subsection{Competition for Substrate and Resources}

As most of the plant pathogens are weak saprophytes, there exists a strong competition in the soil environment for the organic substrates (Cook and Baker 1983). For example, Pythium nunn wins over Pythium ultimum for colonization of added organic compounds, resulting in the death of P. ultimum (Paulitz and Baker 1988).

\subsection{Competition for Root Infection Sites}

As rhizosphere is a rich source of organic substrates for the soil microbes including soil-borne pathogens, the pathogen and the biocontrol agents compete for root colonization and lead to the suppression of the disease (Jambhulkar et al. 2015). For example, non-pathogenic Fusarium equiseti suppress Verticillium wilt by competing with the causal pathogen for root site (Davis et al. 1996).

\subsection{Improving Plant Health Through Induced Systemic Resistance}

One indirect way to suppress disease incidence is to increase plant resistance to soil-borne infections (Jambhulkar et al. 2015). For example, non-pathogenic $F$. oxysporum soil isolates stimulate induced systemic resistance to Fusarium wilt in watermelon (Citrulus lanatus) (Larkin et al. 1996). The resistance is increased with better plant health or modification of certain parts of the plant to reduce infections. In some cases, disease suppression is associated with an increase in physical barriers in plant root such as callus-rich, multi-layered wall appositions (Pharand et al. 2002).

\section{Organic Matter-Mediated Disease Suppression in Soil}

A high SOM content or incorporation of organic manure $(\mathrm{OM})$ into the soils is usually associated with a lower incidence of root diseases. Many scientific reports have addressed the positive effects of compost addition on disease suppressiveness (Alfano et al. 2011; Bonanomi et al. 2007; Chen and Nelson 2008). Application of organic amendments not only manipulates the biological factors but also influences the physical and chemical aspects, thus creating several pathways in disease suppression. Addition of disease-suppressive amendments such as composts enhances the plant defence system through induced system resistance (Yogev et al. 2010) and has an edge over the application of a single bioinoculant. Further, well-prepared compost also contains a multifaceted microbial consortium with diverse mechanisms which cause disease suppression (Barnett et al. 2006). In addition, the efficiency of composts in disease suppression can be enhanced with the inoculation of specific biocontrol agents such as Trichoderma hamatum or Bacillus subtilis (Hadar and Papadopoulou 2012). Several treatments commonly applied to comprehend the mechanisms of disease suppression through the application of composts include sterilization or pasteurization (Cotxarrera et al. 2002; Reuveni et al. 2002; Tilston et al. 2002) or heat treatment of the soil-compost mixture (Serra-Wittling et al. 1996). Such treatments lead to the observations of reduction in the disease-suppressive capacity of the composts, indicating the biological nature of disease suppressiveness. Water extracts collected from several composts are also reported to be suppressive to several soil-borne pathogens although no significant amount of antibiotics and siderophores have been detected in the extracts (El-Masry 
et al. 2002). Such observations provide hints/clues on the major contribution of biological aspects than the physical and chemical perspectives of disease suppression. Another mechanism of biocontrol through composts is the release of toxic or stimulatory volatile compounds that lead to changes in physical and chemical properties of the soil and further affect the development of the pathogens (Coventry et al. 2001; Smolinska 2000; Tilston et al. 2002). Such organic amendments enhance the growth and development of antagonistic microbes such as Lysobacter spp. (L. antibioticus and L. gummosus) which strongly inhibit important soil-borne pathogens such as Rhizoctonia solani (Postma et al. 2010).

Highly suppressive soil could gradually lose its disease suppressiveness under fluctuating environmental conditions (Postma and Schilder 2015). Therefore, in times of low suppressiveness, amending soils with organic materials of different origins could increase the efficiency of disease suppression (Postma and Schilder 2015). Nonetheless, it is not necessary that every organic amendment could stimulate disease suppressiveness in every crop. For example, application of chitin or yeast could not stimulate the antagonistic bacteria Lysobacter spp. in controlling $R$. solani in sugarbeet (Beta vulgaris) (Postma and Schilder 2015) whereas it was successful in radish (Raphanus sativus) and common beans (Phaseolus vulgaris L.) (Henis et al. 1978, 1979). Such fluctuating observations can be expected in a system, which is highly dependent on diverse biological factors. Moreover, the time of analysis or sampling is another strong component while studying the effect of the organic amendments on disease suppression because a sufficient time is required to develop enough population of the specific antagonistic microorganisms after the application of organic material (Akhtar and Alam 1993). It is also essential to study the economic aspects of the amendment application such as chitin that are relatively expensive for agricultural application (Postma and Schilder 2015). Therefore, development of inexpensive agricultural products with reliable effects on disease suppression is an important prerequisite.

Some of the products that could control a pathogen do not necessarily influence soil suppressiveness. For example, biofumigation of brassica seed meal is used to control $R$. solani, but it does not influence soil suppressiveness (Motisi et al. 2010). The original chemical state of the amendments, after application, is also altered by the soil microbiota. The inconsistent results from the use of different organic amendments often make farmers sceptical in the use of organic amendments in disease suppression. Therefore, Bonanomi et al. (2007) evaluated the disease-suppressive capacity of several types of common organic amendments. Out of the total disease incidence, organic amendments could suppress $45 \%$ of the cases, $35 \%$ were non-significant, and the rest $20 \%$ showed an increase of disease incidence (Bonanomi et al. 2007). The addition of organic matter could develop highly suppressive soil (disease reduction more than $80 \%$ ) but limited to only $12 \%$ of all cases (Bonanomi et al. 2007). Moreover, the suppressive ability of the amendments varies significantly with the type of soil-borne pathogens (Bonanomi et al. 2007).

Compost-mediated disease suppression also takes place through the competition of resources between the biocontrol agent in the compost and the pathogen (Jambhulkar et al. 2015). For example, cotton (Gossypium sp.) produces longchain fatty acids such as linoleic acid which is an important stimulant for the spore germination of the pathogen Pythium ultimum that can cause damping-off in cotton (McKellar and Nelson 2003). The biocontrol agent Enterobacter cloacae, inoculated in the compost, metabolizes the fatty acids and prevents the germination of $P$. ultimum, thus suppressing the level of disease incidence. This is the most possible mode of action of $E$. cloacae because it does not produce any inhibitory compounds for the Pythium propagules nor possess any predatory activity (van Dijk and Nelson 2000). In addition, higher populations of linoleic acid metabolizing bacteria are commonly found in suppressive compost than the conducive ones (McKellar and Nelson 2003), suggesting that linoleic acid is a strong determinant in the suppression of disease such as damping-off in cotton. The decomposition phase of the compost has a strong impact on disease suppression (Jambhulkar et al. 2015). Fresh undecomposed compost mixed with bicontrol agents such as Trichoderma does not exert any biological control of pathogens such as $R$. solani. It is because fresh compost represses the synthesis of lytic enzymes from Trichoderma due to high glucose concentrations in fresh compost (Hoitink et al. 2001). The soil ecosystem is at the state of "oligotrophication" during the decomposition of organic matter in soil and, therefore, affects the ratio of K-strategist (oligotrophs) to r-strategist (copiotrophs) during microbial succession (van Bruggen et al. 1999). This ratio is closely associated with general disease suppression (van Bruggen et al. 2000).

\section{Enhancement of Disease Suppression with Biopolymers}

Biopolymers have also been suspected to have the potential to enhance disease suppressiveness in soil (Cretoiu et al. 2013). Application of chitin and/or chitosan extracted from animal waste could temporarily increase root growth and reduce the incidence of nematode infection on plant roots (Green et al. 2006; Radwan et al. 2012; Sarathchandra et al. 1996). Though most of the underlying mechanisms of the disease suppression with biopolymer treatment are still unknown, one of the possible mechanisms could be the change in the diversity and/or activity of soil microbiota that confers the benefits of disease suppression (Mendes et al. 2011). The application of chitin stimulates chitinolytic soil microorganisms, which are capable 
of hydrolysing chitinous fungal hyphae of the pathogens, and the hydrolysed chitin attracts secondary responders and enhances disease suppression (Cretoiu et al. 2013). In this context, several studies have postulated that the addition of chitinous biopolymers to soil stimulates more bacterial communities such as members of the genus Streptomyces (Hjort et al. 2010) than the fungal communities (Gooday 1990; Manucharova et al. 2007). The ubiquitous actinobacteria have been widely studied for their primary role in degrading complex organic molecules such as chitin (Kawase et al. 2006) while some have reported its secondary role in disease suppression (Timmer et al. 2003). Application of biopolymers can be recommended for those soil-borne pathogens that are currently controlled only with the use of some environmentally harmful chemicals. For example, Verticillium wilt, caused mainly by $V$. dahlia, is controlled by the use of volatile chemicals (Giotis et al. 2012). Application of green manure and chitin has been reported to increase disease suppression of $V$. dahliae in the green-house and field studies (Ladner et al. 2008; Kotan et al. 2009). Despite these reports, there are still unexplored areas in disease suppression through the application of biopolymers (Giotis et al. 2012; Ladner et al. 2008). Effects of chitin in relation to crop rotation, soil properties, and nutrient management must be further studied to understand its complex behaviour in disease suppression.

\section{Agricultural Management Regime and Disease Suppression}

\subsection{Crop Selection: an Important Decision in Disease Suppression}

Among several ways to manage the soil microbiome, crop selection is one of the strategies that can alter the physical, chemical, and biological properties of soil in their rhizosphere (Peralta et al. 2018). The resistance of disease differs from one cultivar to another due to their differences in the ecophysiological properties that influence the type and diversity of microbial activity in their rhizosphere (Kobayashi et al. 2015). The resistant cultivars differ from the susceptible ones by their higher microbial diversity, the higher number of putative bacterial interactions, and specific microbial community structure (Kopecky et al. 2019). The composition of the microbial community also changes with the stages of growth of the host plant because of the presence of different types of rhizodeposition during different plant growth stages $(\mathrm{Xu}$ et al. 2012b). However, the dominant mode of biocontrol might not differ along the growth stages (Penton et al. 2014).

Plants can also help in attracting specific antagonistic microorganisms (Peralta et al. 2018) in disease suppressiveness. Depending on the most dominant and active soil-borne pathogen infecting the host species, beneficial Pseudomonads are promising options (Berendsen et al. 2012; Mavrodi et al. 2012). Plants manipulate the soil microbial biota through its specific root exudates (Rudrappa et al. 2008; Shi et al. 2011). The chemical structure of the root exudates directs the type of microbial colonization in the rhizosphere. A mono-cropped cotton exudes more amino acids but less sugar and phenolic acids in its rhizosphere than fallow agricultural soil (control) with the increasing growth phase of the crop (Li et al. 2015). The physiological shift in root exudation systematically affects the plant-microbial interactions. An increase of amino acids (e.g. Glu, Ala, Gly) in the cotton rhizosphere leads to the decrease of beneficial bacteria such as Xanthomonadaceae, Comamonadaceae, and Oxalobacteraceae in the rhizosphere (Minz et al. 2013), thereby reducing the disease-suppressive levels of the soil under mono-cropped cotton (Mendes et al. 2011).

\subsection{Land Use and Its Effects on Disease Suppression}

Natural soil ecosystems are generally more disease suppressive than are arable lands, and such a differential response is attributed mainly to differences in microbial community and structure (Garbeva et al. 2006). The type of plants used as crops in arable land and the naturally grown plants in wild ecosystems differ in their impacts on the characteristics of resident soil microbial communities and, therefore, play different roles in disease suppression (Mazzola and Gu 2002). Higher above-ground biodiversity richness can maintain higher soil microbial diversity (Garbeva et al. 2006). Therefore, land-use changes are often associated with the change in soil microbiota and thus affect disease suppressiveness. This concept of grassland as "preserver of microbial diversity" can be explored to identify more microbial taxa capable of disease suppression. The abundance of DAPG and PRN producers has been reported to increase with plant diversity but with greater spatial diversity (Latz et al. 2012). Therefore, a higher abundance of DAPG and PRN producers is detected in grassland soils than in cultivable soils (Garbeva et al. 2004). Grasses tend to increase the prnD gene abundance whereas legumes decrease DAPG and PRN producer abundance (Latz et al. 2012).

\subsection{The Potential Effects of Conservation Agriculture on Disease Suppression}

Agricultural management regime plays a complex role in developing disease suppression as the outcome may vary and the results are indirect. Effects of long-term use of agricultural management practices such as minimum tillage (Campos et al. 2016; Pankhurst et al. 2002; van Agtmaal et al. 2018), crop rotation (Manici et al. 2005), crop residue retention (Medvecky et al., 2007), and organic farming (Bonanomi et al. 2018a) have been assessed on disease suppressiveness. 
The conventional intensive farming is often associated with increased destruction of soil structure and deterioration of soil health, which lead to decrease in soil biodiversity including the natural enemies and antagonistic microbial community (Crowder and Jabbour 2014). Therefore, it is expected that disease suppression is higher with the use of conservation agriculture (CA) than that with conventional farming practices (Medvecky et al. 2007).

Crop management practices can significantly affect soil microbial diversity and structure involved in disease suppression (Garbeva et al. 2006). CA/no-tillage (NT) often displays positive effects on soil properties (i.e. improvement in waterstable aggregates, increase in SOC, higher pore space, and lower soil bulk density) which make it easy for the soil microorganisms to reproduce and prosper (D'Hose et al. 2018) and promote antagonists of soil-borne pathogens (Peters et al. 2003). The form of disease suppression may vary with the type of crop residues incorporated in the soil in organic farming or with CA. For example, complex lignocellulosic substrates increase the abundance of natural antagonists such as Trichoderma spp. whereas more readily decomposable substrates increase general microbial activity (Medvecky et al. 2007). Although there are mixed responses to input of organic matter to soil suppressiveness, most of the studies have reported positive results (Bailey and Lazarovits 2003). The variability in the response can be attributed to differences in the chemical composition of the organic matter added to the soil (Bonanomi et al. 2018b). The decomposition rate of the organic matter also determines the efficiency of the amendment in disease suppression because the suppressive capacity of the organic amendments can disappear with duration since application (Bonanomi et al. 2018b; Litterick et al. 2004).

The adoption of CA/NT and stubble retention practices can, in some cases, increase soil-borne plant diseases in the short-term (Barnett et al. 2006; Fernandez et al. 2011; Garbeva et al. 2004; Paulitz TC 2006; Weller et al. 2006). However, long-term adoption of crop management practices that supply higher levels of biologically available $\mathrm{C}$ inputs, either through crop residues or the addition of composts and organic manures, can lead to higher levels of disease suppression. This occurs through changes to the composition and activity of soil microbial community (Bonanomi et al. 2010; Gupta et al. 2010, 2011; Postma et al. 2003).

\subsection{Disease Suppression in Organic Farms}

Löbmann et al. (2016) found no difference in disease suppression levels in conventional and organic farms. Similar or equal distribution of disease suppressiveness in conventional and organic sites was also reported by Grünwald and van Bruggen (2000). In contrast, some studies have also reported higher suppressiveness with conventional farming systems than that in organic ones (Knudsen et al. 2002). In general, organic systems have higher disease suppressiveness than conventional systems as the application of organic manure can increase soil biological health (van Bruggen et al. 2015)

\subsection{Rotation Effect and Crop Diversification}

The significance of crop rotation in developing diseasesuppressive soil is colloquially termed as "rotation effect", and it has a long history in agronomic research (Karlen et al. 1994). It has been proved that crop rotation can increase agronomic yield (Karlen et al. 1994; Liebman and Dyck 1993). Crop rotation provides some of the essential ecosystem functions (Zak et al. 2003) such as SOC addition/storage, nutrient cycling, and pest control (Tiemann et al. 2015; Venter et al. 2016). The type of crop used in the rotation has strong implications in developing soil microbial structure. For example, maize is often considered a strong root exuder where $30 \%$ of the total photosynthate is released in the rhizosphere and it supports more diverse groups of soil microbes (Garbeva et al. 2006). However, to elucidate the specific microorganisms from a complex and diverse soil microflora that predominantly contributes to disease suppression is inherently a difficult task.

The increase in yield from crop rotation might be due to crop diversity that decreases soil pathogens although there are mixed evidences on the effect of crop rotation on disease control (Peralta et al. 2018). Another reason for this beneficial effect of crop rotation might be attributed to including nonhost crops in the rotation cycle (Bennett et al. 2012). Crop rotation can enrich specific soil faunal communities in a food web that increases disease suppression in soil (McLaughlin and Mineau 1995). For example, an increase of protist predation on soil bacterial community can lead to the enhanced bacterial DAPG production, thus indirectly activating the disease suppression ability of the bacterial community (Jousset et al. 2008, 2010). Contrary to the conventional results, in some cases, crop rotation can also show a decrease in microbial diversity with the increase in crop diversity (Peralta et al. 2018). Some studies have reported better disease control in monoculture than that in diverse crop rotations. For example, there is a control of take-all disease in wheat monoculture due to the increased abundances of antagonistic Pseudomonas spp. in monoculture than in rotation (Kwak and Weller 2013). The mixed benefits of crop rotations on disease control are related to crop diversity that promotes different pathogen suppressing microbiome. Despite decreased microbial diversity, the disease suppression capacity can be increased with crop diversity due to enrichment of a specific group of soil microorganisms with disease suppression traits (Chaparro et al. 2012). This trend suggests the importance of the composition of soil microbial community rather than diversity in disease suppression. 


\subsection{Stimulation of Disease Suppression with Intercropping and Cover Crops}

Some large-scale field experiments have highlighted the importance of intercropping in increasing total crop yields and disease reduction (Sun et al. 2006). Intercropping could be beneficial in disease suppression against soil-borne bacteria (Michel et al. 1997), fungi (Abdel-Monaim and AboElyousr 2012), and nematode (Dong et al. 2014). For example, pepper (Piper nigrum) monoculture could lead to the outbreak of Phytophthora blight (Yang et al. 2014). Intercropping of maize with pepper could restrict the spread of Phytophthora blight which is attributed to the formation of a "root wall" in maize roots that act as a physical barrier against Phytophthora (Yang et al. 2014). Moreover, maize secretes a significant quantity of antimicrobial compounds that inhibit the growth and spread of the pathogen (Yang et al. 2014).

Similarly, the inclusion of cover crops is a promising option in agricultural management practices as it can improve soil properties (McDaniel et al. 2014; Tilman et al. 2002, 2015). Cover crops, in combination with crop rotation, can enhance the abundance of prnD gene (Peralta et al. 2018) and influence the disease-suppressive potential of the soil. Thus, it is not surprising that cover crops can influence several physical and chemical properties of soil that likely have large indirect impacts on soil microbial community (Peralta et al. 2018). Previous studies have reported the immediate effects of cover crops on soil microbial activities (Finney et al. 2017). In the physical aspect, cover crops can enhance plant water availability by improving soil structure, reducing soil bulk density, and increasing soil aeration (Tiemann et al. 2015) that can significantly affect soil bacterial community as well. Several studies have correlated the expression of antimicrobial genes and soil factors such as soil texture and nutrient availability (Imperiali et al. 2017; Raaijmakers et al. 2009). In chemical aspects, cover crops enhance SOC content through the decomposition of crop residues and the release of exudates from plant roots (Neumann and Romheld 2007). Soil microbial activities are stimulated as a result of increased $\mathrm{C}$ flow from root exudates released from cover crops. Therefore, with the difference in quantity and quality of the root exudates from cover crops, there is a shift in microbial community composition, either from a diverse to specific or vice-versa (Dijkstra et al. 2010).

\subsection{Reductive Soil Disinfestation}

Another form of soil management practice is reductive soil disinfestation (RSD), a pre-plant soil disinfestation practice in which organic matter is incorporated into the soil before planting followed by irrigation to maximum field capacity and covering the soil with plastic film (Blok et al. 2000; Liu 2019).
RSD has been reported to increase tolerance to soil-borne pathogens in upland-paddy rotation (Momma et al. 2013). RSD treatment enhances the production of antagonistic compounds, manganese, ferrous cations, and ammonia that help in suppressing a wide range of soil-borne pathogens (Butler et al. 2014; Hewavitharana et al. 2014; Huang et al. 2016a, b; Momma et al. 2013). RSD indirectly influences disease suppression by improving soil properties such as $\mathrm{pH}$, electrical conductivity, microbial population, and SOC content (Huang et al. 2016b; Huang et al. 2017; Strauss et al. 2017). Thus, RSD is considered an alternative to chemical fumigation in several countries including Japan, the USA, and China (Butler et al. 2014; Hewavitharana et al. 2014; Huang et al. 2016a, b; Momma et al. 2013).

\section{Unravelling Soil Microbiome for Antibiotics and Drugs}

Majority of the research on DSS is restricted to easily cultural bacteria with fast growth rate in vitro (Frapolli et al. 2008). Culture-independent metagenomics studies have shown that the top $10 \%$ of most dynamic taxa found in suppressive soil belong to actinobacteria (Cordovez et al. 2015). Existing conventional microbial cultivation approaches could exploit only a minor fraction of soil microbiota (Janssen et al. 2002). Therefore, molecular-based techniques, which derive the results from a direct exploration of soil extracted DNA, are increasingly used in disease suppression studies (Lefevre et al. 2008) (Fig. 5).

Although a number of medicines have been developed from soil biota to control diseases, infectious diseases such as COVID-19 remain one of the prominent causes of human death worldwide (Chakraborty and Maity 2020; O’Neill 2016). By the year 2050, it is predicted that mortality rates due to the infectious diseases will increase more than tenfold (Hover et al. 2018). Therefore, to come up with new effective antibiotics, the search for new bacteria that could produce new bioactive bacterial metabolites has led to the global search in natural ecosystems such as soil system that harbours around 10,000 unique bacterial species (Guerra et al. 2020). Although $1,500,000$ fungi species have been estimated, it is rather difficult to grow them by standard methods (Kirk et al. 2004). Another class of soil microorganisms mined for antibiotics is actinomycetes (diverse family of soil bacteria). Actinomycetes have numerous uses in the pharmaceutical industry as they are a potential source of bioactive compounds (Villarreal-Gómez et al. 2013). As much as $80 \%$ of the world antibiotics are derived from the genera Micromonospora and Streptomyces (Villarreal-Gómez et al. 2013).

The linkage between soil and human health is recognized for thousands of years ago (Brevik, 2009; Brevik and Burgess 2013). The transfer of essential nutrients from the soil to 
human beings through plants and animals and direct ingestion is one of the linkage examples (Brevik and Burgess 2013; Oliver and Gregory 2015). The microbial drug era started around 1929 when Alexander Fleming discovered penicillin from the fungus Penicillium notatum grown on Staphylococcus aureus. The reason to mine antibiotics from soil microorganisms rather than synthetic production of antimicrobial drugs is due to the poor penetration of the antimicrobial drugs into the target cells (Payne et al. 2007). On the other hand, natural compounds synthesized from soil microbes are evolved in such a manner that it can easily pass through the penetration barriers of the target bacteria (Lewis 2012). Therefore, screening and isolating soil microorganisms is one of the most prominent drug mining procedures (Peek et al. 2018). As soils are highly heterogeneous in nature and have large variations in properties with spatial-temporal changes, it has led to the development of most diverse populations of soil bacteria of any environment on the Earth (Guerra et al. 2020; Raaijmakers and Mazolli 2012). Despite its heterogeneity, only around $1-5 \%$ of the soil microbes are culturable under in vitro conditions (Clardy et al. 2006). Another major concern in the public health sector is the increasing speed of antibiotic resistance that has outnumbered the introduction of new compounds in clinical practice (Ling et al. 2015). Thus, over mining of this small portion of culturable bacteria calls for the need of drug discovery from the unculturable section of soil microbes (that cannot be grown under laboratory conditions) (Fig 6). Methods such as growing/cultivating the uncultured microorganisms in natural environments (Kaeberlein et al. 2002; Nichols et al. 2010) or addition of specific growth factors such as siderophores (D'Onofrio et al. 2010) are employed to study the unculturable microorganisms.

The discovery of new antibiotics from soil microbial natural product (NP) starts with the collection and isolation of required soil microorganisms (Pela'ez 2006). They are grown in conditions required for their growth and development and certain growth factors are added to induce production of desired metabolite (Fig. 7) (Pela'ez 2006). The natural metabolites are then extracted and tested. The specific compound needs to be isolated and purified from other mixtures before it is formulated as new drugs. The list of the natural products isolated from soil microorganisms that are found to be effective towards antibiotic-resistant pathogens is shown in Table 1.

As soils are ubiquitous with the myriad of soil microorganisms, molecules isolated from bacteria collected from remote environments such as oceans have been found subsequently related with molecules isolated from soil system (CharlopPowers et al. 2016). In some cases, macrolactins isolated from marine microorganisms (Gustafson et al. 1989) were later proved to be encoded by a common soil rhizospheric bacteria Bacillus species (Chen et al. 2007). The antibiotics-producing bacteria in soil are so diverse that it can differ significantly even with the level of urbanization. Charlop-Powers et al. (2016) assessed the biosynthetic capacity of urban soil environments through a phylogenetic analysis process of NP biosynthetic genes. Distinct features in diversity and biosynthetic capacities were found in urban and non-urban soil samples. These results could change the idea of "systematic exploration of soil bacteria only in natural environments" as CharlopPowers et al. (2016) indicated that urban soil microbiomes likely hold similar promise in exploring new sources of NPs.

In addition to difficulties of growing the bacteria under laboratory conditions, only a fraction of the chemistries encoded by cultured bacteria can be detected in fermentation experiments (Hover et al. 2018). Most of the natural products (NPs) from bacteria such as malacidins (a distinctive class of antibiotics) remain undiscovered in the global soil microbiome (Hover et al. 2018). A culture of independent NP discovery platform, developed by Hover et al. (2018), is aimed at accessing these hidden NPs. It includes a series of sequencing, bioinformatics analysis, and heterologous expression of biosynthetic gene clusters captured on DNA extracted from environmental samples. It is these extracts through which antibiotics that are commonly encoded in soil

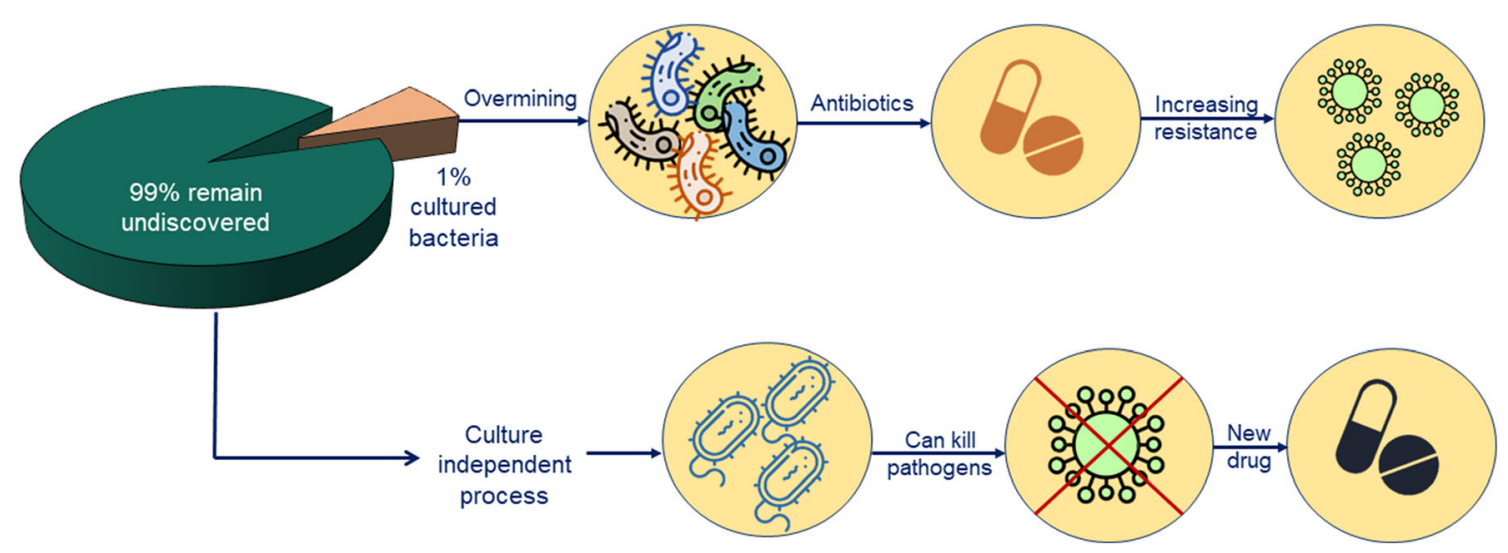

Fig. 6 The need for the discovery of new antibiotics from the uncultured portion of soil microbes (source: developed by author from a number of literature sources) 
Table 1. List of the bioactive compounds isolated from soil microbiome

\begin{tabular}{|c|c|c|c|c|}
\hline Soil microorganism & Bioactive compounds & Bioactivity & Mechanisms & References \\
\hline $\begin{array}{l}\beta \text {-proteobacteria } \\
\text { provisionally named } \\
\text { Eleftheria terrae }\end{array}$ & Teixobactin & $\begin{array}{l}\text { Kill Staphylococcus aureus } \\
\text { or Mycobacterium } \\
\text { tuberculosis resistant }\end{array}$ & $\begin{array}{l}\text { Inhibits cell wall synthesis by binding to a } \\
\text { highly conserved motif of lipid II and } \\
\text { lipid III }\end{array}$ & Ling et al. (2015) \\
\hline $\begin{array}{l}\text { Streptomyces strain } \\
\text { PM0324667 }\end{array}$ & NFAT-133 & Antidiabetic & $\begin{array}{l}\text { Induced glucose uptake in L6 skeletal } \\
\text { muscle cells }\end{array}$ & $\begin{array}{l}\text { Mayer et al. } \\
\quad(2011)\end{array}$ \\
\hline $\begin{array}{l}\text { Clostridium } \\
\text { cellulolyticum }\end{array}$ & Closthioamide & Antibiotic & Staphylococci multiresistant inhibition & $\begin{array}{l}\text { Kulkarni-Almeida } \\
\text { et al. (2011) }\end{array}$ \\
\hline $\begin{array}{l}\text { Uncultured soil } \\
\text { microbiome }\end{array}$ & Malacidins & $\begin{array}{l}\text { Calcium-dependent } \\
\text { antibiotics }\end{array}$ & $\begin{array}{l}\text { Kills multidrug-resistant Gram-positive } \\
\text { pathogens }\end{array}$ & Hover et al. (2018) \\
\hline $\begin{array}{l}\text { Gordonia sputi DSM } \\
\quad 43896\end{array}$ & G48 JF905613 Compound & Antimicrobial & C. albicans, S. aureus inhibition & $\begin{array}{l}\text { Lincke et al. } \\
\text { (2010) }\end{array}$ \\
\hline Unspecified & Kanglemycins/Kangs & Rifamycin antibiotics & $\begin{array}{l}\text { Target rifamycin-resistant pathogens such } \\
\text { as Mycobacterium tuberculosis }\end{array}$ & Peek et al. (2018) \\
\hline Actinomycetes & 3Ba3 Compound & Antibacterial & $\begin{array}{l}\text { E. amylovora, P. viridiflova, } \\
\text { A. tumefaciens, B. subtilis ATCC } 663 \text {, } \\
\text { E. coli ATCC } 299983 \text { inhibition }\end{array}$ & Lee et al. (2012) \\
\hline Micromonospora sp. & Diazepinomicin/ECO-4601 & Antimicrobial & Unspecific & Oskay et al. (2004) \\
\hline
\end{tabular}

microbiomes were discovered. These are found to be active against multidrug-resistant pathogens and can sterilize methicillin-resistant Staphylococcus aureus that causes skin infections in an animal wound (Hover et al. 2018).

In the case of tuberculosis caused by Mycobacterium tuberculosis $(T B)$, development of resistance towards antibiotic treatment is steadily rising and is creating a major problem in treating TB-infected patients (Chakraborty and Rhee 2015). The effectiveness of the current drugs such as antibiotic rifamycin (semi-synthetic derivatives of the bacterial natural product) is threatened in treating TB patients as the mycobacterium often mutates itself and develops its resistance towards the antibiotic treatment (Zumla et al. 2015). In general, rifamycin targets the RNA polymerase (RNAP) of the mycobacterium as RNAP is an important enzyme for the survival of the bacteria (Ramaswamy and Musser 1998). However, this attack mechanism might not work in a mutated mycobacterium as it would not allow the binding of rifamycin to the enzyme (Perron et al. 2015). Therefore, alternatives to the rifamycin need to be manufactured in such a form that the new drug should act like rifamycin but has an additional property to inhibit the growth and survival of the mutated
Fig. 7 Schematic step-wise process of antibiotic drug discovery from soil microorganisms (modified from Pela'ez 2006).

(Developed by authors from a number of literature sources)

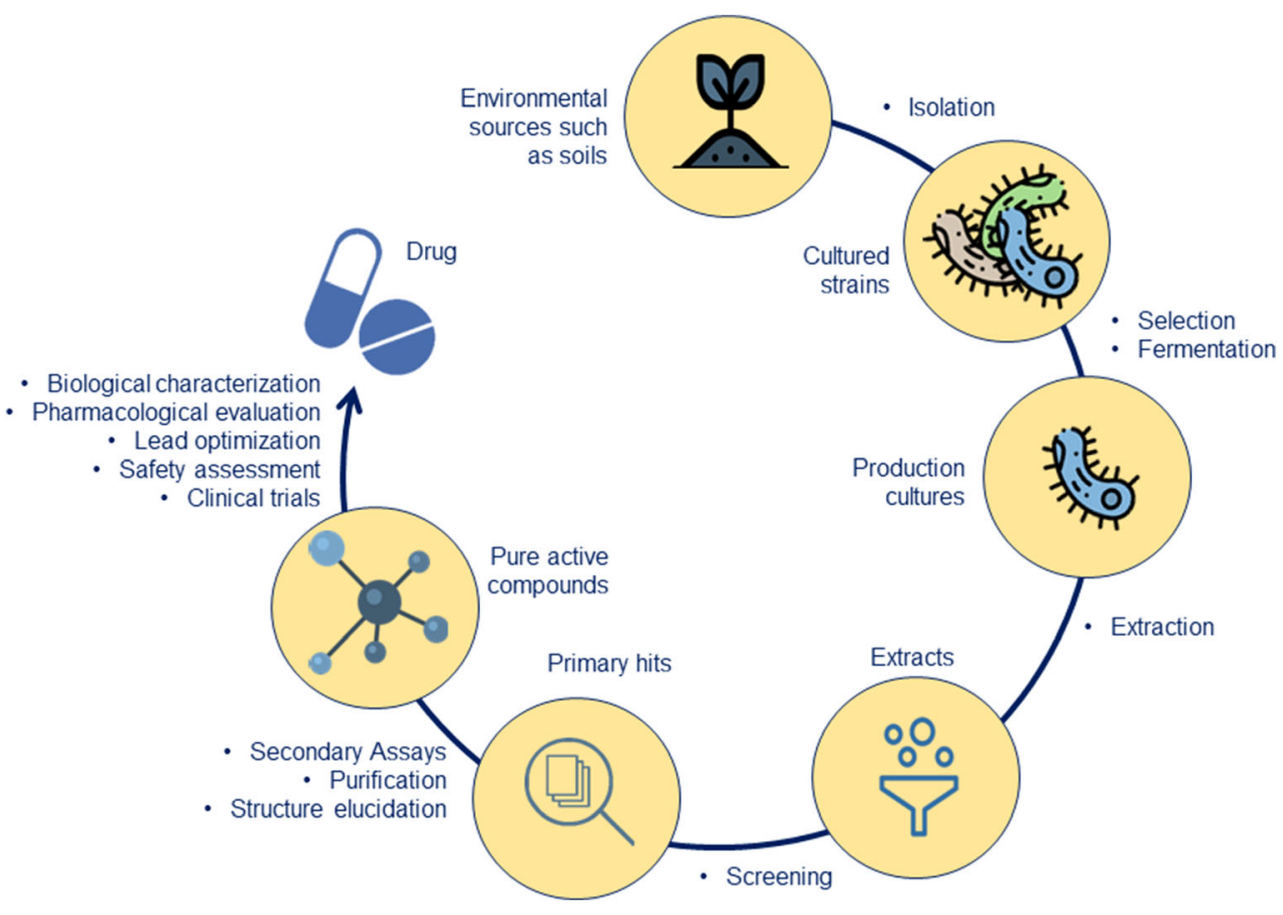


mycobacterium (Peek et al. 2018; Perron et al. 2015). As rifamycin is a naturally produced antibiotic by a bacterium, it was also essential to investigate any rifamycin analogues (like rifamycin but have slight differences in chemical properties) present in the natural ecosystem (Strieker and Marahiel 2009). Therefore, Peek et al. (2018) discovered another group of natural antibiotics from soil called "kanglemycins" or "kangs", having most of the similar genes with rifamycin. The development of kangs in the soil might be attributed to the competition between the soil microbes through the production of toxins such as rifamycin that led to the evolution of rifamycin congeners produced by rival bacteria (Peek et al. 2018). The examination of gene clusters recovered from soil metagenomes explained the evolution of such new molecules from an ancestral rifamycin-like gene cluster with the help of horizontal gene transfer process (Peek et al. 2018). Gavrish et al. (2014) identified a ribosomally synthesized cyclic peptide called "Lassomycin" from uncultured microorganisms that inhibits Mycobacterium tuberculosis by targeting the ATP-dependent protease ClpC1P1P2. Another example is the production of secondary metabolites by an uncultured soil symbiotic Entotheonella sp. (Wilson et al. 2014). Using the untapped source of new antibiotics from the uncultured soil microorganisms, Ling et al. (2015) reported another form of antibiotic "Teixobactin" that inhibits the cell wall synthesis of Staphylococcus aureus or Mycobacterium tuberculosis through binding to a highly conserved motif of lipid II (precursor of peptidoglycan) and lipid III (precursor of cell wall teichoic acid). Thus, teixobactin could be another promising therapeutic antibiotic produced from soil microbes against drug-resistant pathogens.

\section{Complexities in Studying Disease-Suppressive Soils}

Knowing the potential of disease-suppressive soils, studies attempting to control soil-borne diseases such as verticillium wilt, blight, root rot, and bacterial wilt through artificial construction of diverse microbial communities have been accelerating (Gao et al. 2019). The natural soil disease suppressiveness involves far more than the extensively discussed biocontrol agents or antagonists (Ramette et al. 2006). Indeed, as the rhizosphere microbial community is highly diverse and dynamic in nature, several other microbial taxa could have played an important role in disease suppression either by releasing pathogen inhibitors (Raaijmakers et al. 2009) or by enhancing plant growth and resistance (Bally and Elmerich 2005). Plants are often considered the main influencer of soil microbial community composition and diversity (Wieland et al. 2001). However, the underlying mechanisms of the influence of crop management on the microbial community are still limited (Garbeva et al. 2004).
Since Baker and Snyder (1965) first discussed the DSS, attempts have been made in several locations to develop soil suppressiveness through inoculation of biocontrol agents in soil (Fravel 2005). However, knowing the complexity of the biochemical and ecological interactions between the host plant and the pathogens, it is unlikely for developing DSS to succeed (Janczura et al. 2006). The existence of heterogeneous soil ecosystems and a large number of farming practices make it difficult to evaluate the specific conditions needed for developing and maintaining DSS in cultivable lands (Alabouvette and Steinberg 2006). Although disease suppression largely depends on soil and weather conditions, soil disease suppressiveness at the same site may vary with the type of long-term management practices (Tamm et al. 2010). Therefore, manipulation of soil management practices has a large potential in suppressing soil-borne diseases (Ghorbani et al. 2008).

Despite the fact that disease suppressiveness is regarded as an important component of soil quality (van Bruggen and Semenov 2000), it is not well understood even though a corpus of documentation has been released. The issue in studying the mechanisms of disease suppression is the inability to accurately identify the actual causal agent of the disease suppression. The positive or negative correlations between the pathogen abundance and the antagonistic population only suggest the possible role of the antagonistic bacteria in disease suppression. Therefore, unravelling the complex mechanisms of soil-related disease suppressiveness after the application of organic materials remains a researchable issue. Although the actual extent of soil microbial diversity is not yet known, the soil system is the largest reservoir of biological diversity on Earth (Guerra et al. 2020; Kirk et al. 2004). The infection of a host plant by a pathogen can trigger and manipulate the rhizosphere of the conducive soil in such a way that the other pathogens are developed in the rhizosphere. For example, in a mono-cropped cotton soil, specific populations of Flavobacteriaceae, Streptomycetaceae, and Sphingomonadaceae are significantly increased in the rhizosphere ( $\mathrm{Li}$ et al. 2015) after the infection of cotton with Fusarium oxysporum. Similarly, Jack et al. (2013) also found relatively higher populations of Flavobacteriaceae and Phyllobacteraceae in conducive soil than diseasesuppressive soils. This trend might be attributed to the root necrosis that further causes leakage of organic root compounds which stimulate a distinct ecological condition for microbial colonization (Kyselková et al. 2009). Higher abundance of Flavobacteriaceae, Streptomycetaceae, and Sphingomonadaceae are found in the conducive soil after infection as they can actively produce cellulose, pectin, and chitin decomposing enzymes that feed on the root leakage constituents (Beier and Bertilsson 2013; Manucharova et al. 2007). Therefore, the concomitant occurrence of these taxa with the specific pathogens in the rhizosphere of the host 
plants causes greater damage in a conducive soil (Chen et al. 2014) and working on a specific group of antagonists might not work in these cases. The nature of the soil-related disease suppressiveness is highly unpredictable because of the complex interactions of different pathogenic and beneficial microbes and the heterogeneities of soil and weather at the field, landscape, and regional level.

The organic amendments prepared from the same base material may differ in disease-suppressive potential. For example, compost made from the middle part of hardwood bark is often less suppressive to disease development than when it is produced from the thermophilic region with lesser microbial activity and higher reducing sugars (Jambhulkar et al. 2015). However, the conducive material when incubated at room temperature can become suppressive with the increase of microbial activity and decline in reducing sugar levels (Stone et al. 2004).

\section{Impact of Climate Change on DSS and Food Security}

According to Oerke (2006), plant diseases could threaten up to $82 \%$ of attainable yield in cotton and more than $50 \%$ for most of the major crops. These yield losses due to plant diseases are a huge concern, especially in resource-poor countries (Chakraborty and Newton 2011; Döring et al. 2020). Several authors highlight the "fertilization effect" of increasing atmospheric $\mathrm{CO}_{2}$ that might help in increasing food production (Ainsworth and Long 2005). Even though there is a possibility of the fertilization effect, it may be outweighed due to climate change-mediated increase in plant diseases (Butterworth et al. 2010; Dawson et al. 2016). The impacts of plant diseases under increasing climate change are mostly ignored in several global food security assessments (Dawson et al. 2016; Fernandes et al. 2004). In order to secure sufficient and nutritious food for the expanding human population, an increase in the incidence of plant disease will demand more pesticide usage (Chakraborty and Newton 2011). This also highlights the future need for DSS as a cost-effective and environmentfriendly disease management technique that could be pursued by growers. Therefore, continuous exploration and research on the impacts of climate change on DSS must be carried out to illustrate the changes in pathogen-soil-plant-environment complex and secure a sustainable future for an ever-expanding population.

While we are worried about the impacts of rising temperature stress on crop production (Dawson et al. 2016), there is complete lack of sufficient quantitative evidences on use of DSS in climate change conditions (Pautasso et al. 2012). The possible effects of climate change on plant diseases include acceleration of pathogen evolution, shorter incubation periods, early attack of the disease, higher susceptibility of the host plants to soil-borne pathogens, and geographical expansion of plant diseases (Döring et al. 2020). While few soilborne pathogens, such as Pythium cinnamon, showed a null response to climate change (Thompson et al. 2014), others have demonstrated a reduction of disease suppressiveness against Rhizoctonia solani after heat treatment of the soil (50 $\left.{ }^{\circ} \mathrm{C}\right)$ (der Voort et al. 2016). The combined heat and drought stress could reduce the disease suppressiveness of the test soils (Döring et al. 2020), although the change varies in different soils due to differences in soil microbial community. Soils from dry and arid areas or located in high altitude with summer temperatures, and that has been already experienced heat stress are more vulnerable to decrease its disease suppressiveness due to predicted temperature rise in future (Döring et al. 2020). Such experiments could also show recovery of the soil microbial communities after the removal of temperature stress (Griffiths and Philippot 2013). Soil physical and chemical properties, through their effects on soil microbial community, could govern the resistance and resilience of DSS (Griffiths and Philippot 2013). Soil abiotic characteristics are closely linked with the soil biological and physical resilience (Gregory et al. 2009). Higher organic matter and clay contents positively affect the resilience of DSS (Gregory et al. 2009). Therefore, keeping these views in mind, future studies must be conducted to understand the relationships between soil abiotic factors and soil resilience in DSS.

\section{Future Perspectives on DSS}

Although it has been a primary goal of plant breeders to develop high-yielding plant cultivars, tools to develop cultivars which develop selective microbial communities in the rhizosphere, are still lacking. In-depth studies are needed to understand the complexities of soil microbial community interactions in DSS which can enhance the melding of this information with plant breeding strategies for improving disease suppression. However, several questions need to be answered through future studies on DSS. And important among these include: are there any genotype differences of 2, 4-DAPG producers in disease-suppressive capacities? Although soil disease suppressiveness is closely associated with the microbial community, a few questions remain in respect to the compatibility of the soil microbes among each other and their associated effects on disease suppression. Why the crop monoculture can enrich the population of 2, 4-DAPG producers remains to be answered. Future biological studies of soil suppressiveness need to generate new insights into the microbial soil ecology, which can serve as a foundation for the development of cost-effective and environmentally friendly management strategies for disease suppression. It is still a challenge to further develop molecular assessment tools (including specialized DNA microarrays and metagenomics) to 
unravel the antagonistic behaviour of soil towards soil-borne pathogens. In addition, the complex interactions between two main drivers of DSS (i.e. abiotic and biotic factors) and their fluctuations must be further studied. The intricate knowledge of DSS can be broadened with the promotion of collaborations between soil microbiologists, soil microbial ecologists, plant pathologists, physiologists, soil scientists, and agronomists. This multi-disciplinary approach is needed to understand the complexity of the DSS system and simplify the painstaking process of identifying, decoding the mechanisms of DSS, and widen its practical applications.

\section{Conclusions}

This review paper has highlighted various aspects of disease-suppressive soils, challenges, prospects, and benefits. Disease-suppressive soil is one of the under-utilized resources for crop protection by improving soil health. Earlier research was focused on the identification of the biotic and abiotic factors responsible for soil disease suppressiveness, but there is an increasing trend of studies based on molecular and culture-independent approaches that make it possible to decipher the underlying mechanisms of disease suppressiveness. Understanding the interactions of plant-pathogen with beneficial soil microbes could provide opportunities for novel crop protection against soil-borne diseases. There is an urgent need to identify the specific patterns in the relationship between microbial diversity and ecosystem functioning to have a proper insight into microbiome management that will also require proper manipulation of soil nutrients and other soil properties mediated through plant diversity. In a nutshell, disease-suppressive soil is a promising option, yet requires further understanding of the complexity of the biochemical and ecological interactions between the host plant and the pathogens. Thus, detailed studies on molecular and culture-independent approaches are necessary to decipher the underlying mechanisms of disease suppressiveness in the soil for harnessing the greater benefits of "soil microbiome". Further examination of uncultured microorganisms in natural environments such as for the production of new antibiotics, teixobactin on the native soil solution and addition of specific growth factors such as siderophores are among promising options.

\footnotetext{
Abbreviations AM, Arbuscular mycorrhizal; CEC, Cation exchange capacity; C, Carbon; DAPG, 2, 4 -Diacetyl phloroglucinol; DSS, Disease-suppressive soils; DCS, Disease-conducive soils; GSM, General suppression mechanism; PRN, Pyrrolnitrin; SSM, Specific suppression mechanism; SOM, Soil organic matter; SOC, Soil organic carbon; T-RFLP, Terminal restriction fragment length polymorphism; VOCs, Volatile organic compounds
}

\section{Declarations}

Conflict of Interest The authors declare no competing interests.

\section{References}

Abdallah RZ, Wegner CE, Liesack W (2019) Community transcriptomics reveals drainage effects on paddy soil microbiome across all three domains of life. Soil Biol Biochem 132:131-142. https://doi. org/10.1016/j.soilbio.2019.01.023

Abdel-Monaim MF, Abo-Elyousr KA (2012) Effect of preceding and intercropping crops on suppression of lentil damping-off and root rot disease in New Valley, Egypt. Crop Protection 32:41-46. https:// doi.org/10.1016/j.cropro.2011.10.011

Adam M, Westphal A, Hallmann J, Heuer H (2014) Specific microbial attachment to root knot nematodes in suppressive soil. Applied and Environ Microbiol 80(9):2679-2686. https://doi. org/10.1128/AEM.03905-13

Adesina MF, Lembke A, Costa R, Speksnijder A, Smalla K (2007) Screening of bacterial isolates from various European soils for in vitro antagonistic activity towards Rhizoctonia solani and Fusarium oxysporum:site- dependent composition and diversity revealed. Soil Biol Biochem 39:2818-2828. https://doi.org/10.1016/j. soilbio.2007.06.004

Ainsworth EA, Long SP (2005) What have we learned from 15 years of free-air $\mathrm{CO} 2$ enrichment (FACE)? A meta-analytic review of the responses of photosynthesis, canopy properties and plant production to rising $\mathrm{CO}_{2}$. New Phytologist 165:351-372. https://doi.org/10. 1111/j.1469-8137.2004.01224.x

Akhtar M, Alam MM (1993) Utilization of waste materials in nematode control: a review. Bioresour Technol 45:1-7. https://doi.org/10. 1016/0960-8524(93)90134-w

Alabouvette C (1986) Fusarium wilt suppressive soils from the Chateaurenard region: review of a 10-year study. Agronomie 6: 273-284. https://doi.org/10.1051/agro:19860307

Alabouvette C, Lemanceau P, Steinberg C (1993) Recent advances in the biological control of Fusarium wilts. Pestic Sci 37:365-373

Alabouvette C, Steinberg C (2006) The soil as a reservoir for antagonists to plant diseases. In: Eilenberg J, Hokkanen HMT (eds) An Ecological and Societal Approach to Biological Control. Springer, Dordrecht, pp 123-144. https://doi.org/10.1007/1-4020-4401-1 8

Alfano G, Lustrato G, Lima G, Vitullo D, Ranalli G (2011) Characterization of composted olive mill wastes to predict potential plant disease suppressiveness. Biological Control 58:199-207. https://doi.org/10.1016/j.biocontrol.2011.05.001

Allison SD, Martiny JBH (2008) Resistance, resilience, and redundancy in microbial communities. Proc Natl Acad Sci USA 105:1151211519. https://doi.org/10.1073/pnas.0801925105

Amir H, Alabouvette C (1993) Involvement of soil abiotic factors in the mechanisms of soil suppressiveness to Fusarium wilts. Soil Biol Biochem 25:157-164. https://doi.org/10.1016/00380717(93)90022-4

Andrade OA, Mathre DE, Sands DC (1994) Suppression of Gaeumannomyces graminis var. tritici in Montana soils and its transferability between soils. Soil Biol Biochem 26:397-402. https://doi.org/10.1016/0038-0717(94)90289-5

Andrivon D (1994) Dynamics of the survival and infectivity to potato tubers of sporangia of Phytophthora infestans in three different soils. Soil Biol Biochem 26:945-952. https://doi.org/10.1016/00380717(94)90107-4

Anton T (2017) Planet of Microbes: The Perils and Potential of Earth's Essential Life Forms. University of Chicago Press. https://doi.org/ 10.7208/chicago/9780226354132.001.0001 
Bailey KL, Lazarovits G (2003) Suppressing soil-borne diseases with residue management and organic amendments. Soil Till Res 72: 169-180. https://doi.org/10.1016/s0167-1987(03)00086-2

Bailly A, Weisskopf L (2012) The modulating effect of bacterial volatiles on plant growth: current knowledge and future challenges. Plant Signal Behav 7:79-85. https://doi.org/10.4161/psb.7.1.18418

Baker KF, Snyder WC (1965) Ecology of Soil-Borne Plant Pathogens: Prelude to Biological Control. University of California Press, California. https://doi.org/10.2307/3756904

Bally R, Elmerich C (2005) Biocontrol of plant diseases by associative and endophytic nitrogen-fixing bacteria. In: Elmerich $\mathrm{C}$, Newton WE (eds) Associative and Endophytic Nitrogen-fixing Bacteria and Cyanobacterial Associations. Kluwer Academic Publishers, Dordrecht, pp 171-190

Barea JM, Tobar RM, Azcon-Aguilar C (1996) Effect of a geneticallymodified Rhizobium meliloti inoculant on the development of arbuscular mycorrhizas, root morphology, nutrient uptake and biomass accumulation in Medicago sativa L. New Phytol 134:361369. https://doi.org/10.1111/j.1469-8137.1996.tb04641.x

Barnett SJ, Roget DK, Ryder MH (2006) Suppression of Rhizoctonia solani AG-8 induced disease on wheat by the interaction between Pantoea, Exiguobacterium, and Microbacteria. Aust J Soil Res 44: 331-342. https://doi.org/10.1071/sr05113

Beier S, Bertilsson S (2013) Bacterial chitin degradation-mechanisms and ecophysiological strategies. Front Microbiol 4:149. https://doi. org/10.3389/fmicb.2013.00149

Benizri E, Piutti S, Verger S, Pages L, Vercambre G, Poessel J, Michelot P (2005) Replant diseases: bacterial community structure and diversity in peach rhizosphere as determined by metabolic and genetic fingerprinting. Soil Biology and Biochemistry 37:1738-1746. https://doi.org/10.1016/j.soilbio.2005.02.009

Bennett AJ, Bending GD, Chandler D, Hilton S, Mills P (2012) Meeting the demand for crop production: the challenge of yield decline in crops grown in short rotations. Biol Rev 87:52-71. https://doi.org/ 10.1111/j.1469-185x.2011.00184.x

Berendsen RL, Pieterse CM, Bakker PA (2012) The rhizosphere microbiome and plant health. Trends Plant Sci. 17:478-486. https://doi.org/10.1016/j.tplants.2012.04.001

Blok WJ, Lamers JG, Termorshuizen AJ, Bollen GJ (2000) Control of soilborne plant pathogens by incorporating fresh organic amendments followed by tarping. Phytopathology 90:253-259. https:// doi.org/10.1094/phyto.2000.90.3.253

Bonanomi G, Antignani C, Pane C, Scala F (2007) Suppression of soil borne fungal diseases with organic amendments. J Plant Pathol 89(3):311-324

Bonanomi G, Antignani V, Capodilupo M, Scala F (2010) Identifying the characteristics of organic soil amendments that suppress soilborne plant diseases. Soil Biol Biochem 42:136-144. https://doi.org/10. 1016/j.soilbio.2009.10.012

Bonanomi G, Cesarano G, Antignani V, Di Maio C, De Filippis F, Scala F (2018a) Conventional farming impairs Rhizoctonia solani disease suppression by disrupting soil food web. J Phytopath. 166(9):663673. https://doi.org/10.1111/jph.12729

Bonanomi G, Lorito M, Vinale F, Woo SL (2018b) Organic amendments, beneficial microbes, and soil microbiota: toward a unified framework for disease suppression. Annual Review of Phytopath 56:120. https://doi.org/10.1146/annurev-phyto-080615-100046

Boukaew S, Plubrukam A, Prasertsan P (2013) Effect of volatile substances from Streptomyces philanthi RM-1-138 on growth of Rhizoctonia solani on rice leaf. Bio Control 58:471-482. https:// doi.org/10.1007/s10526-013-9510-6

Brader G, Compant S, Mitter B, Trognitz F, Sessitsch A (2014) Metabolic potential of endophytic bacteria. Curr Opin Biotechnol 27:30-37. https://doi.org/10.1016/j.copbio.2013.09.012

Brady NC (1984) The nature and properties of soils. Macmillan Publishing Co., Inc., Englewood Cliffs
Brevik EC (2009) Soil, food security, and human health. In: Soils, Plant Growth and Crop Production. In: Verheye W (ed) Encyclopedia of Life Support Systems (EOLSS), Developed under the Auspices of the UNESCO. EOLSS Publishers, Oxford

Brevik EC, Burgess LC (2013) Soils and Human Health. CRC Press, Boca Raton, FL

Butler DM, Kokalis-Burelle N, Albano JP, McCollum TG, Muramoto J, Shennan C, Rosskopf EN (2014) Anaerobic soil disinfestation (ASD) combined with soil solarization as a methyl bromide alternative: vegetable crop performance and soil nutrient dynamics. Plant Soil 378:365-381. https://doi.org/10.1007/s11104-014-2030-z

Butterworth MH, Semenov M, Barnes AP, Moran D, West JS, Fitt BDL (2010) North-south divide; contrasting impacts of climate change on crop yields in Scotland and England. J Royal Soc Interface 7:123130. https://doi.org/10.1098/rsif.2009.0111

Campos SB, Lisboa BB, Camargo FAO, Bayer C, Sczyrba A, Dirksen P, Albersmeier A, Kalinowski J, Beneduzi A, Costa PB, Passaglia LMP, Vargas LK, Wendisch VF (2016) Soil suppressiveness and its relations with the microbial community in a Brazilian subtropical agroecosystem under different management systems. Soil Biol Biochem 96:191-197. https://doi.org/10.1016/j.soilbio.2016.02.010

Cao Y, Wang J, Wu H, Yan S, Guo D, Wang G, Ma Y (2016) Soil chemical and microbial responses to biogas slurry amendment and its effect on Fusarium wilt suppression. Appl Soil Ecol 107:116123. https://doi.org/10.1016/j.apsoil.2016.05.010

Cao ZH, Huang JF, Zhang CS, Li AF (2004) Soil quality evolution after land use change from paddy soil to vegetable land. Environ Geochem Health 26:97-103. https://doi.org/10.1023/B:EGAH. 0000039572.11564 .27

Cardoso IM, Kuyper TW (2006) Mycorrhizas and tropical soil fertility. Agric Ecosyst Environ 116:72-84. https://doi.org/10.1016/j.agee. 2006.03.011

Cha JY, Han S, Hong HJ, Cho H, Kim D, Kwon Y, Kwon SK, Crusemann M, Lee YB, Kim JF, Giaever G, Nislow C, Moore BS, Thomashow LS, Weller DM, Kwak YS (2016) Microbial and biochemical basis of a Fusarium wilt-suppressive soil. ISME J 10: 119-129. https://doi.org/10.1038/ismej.2015.95

Chakraborty I, Maity P (2020) COVID-19 outbreak: migration, effects on society, global environment and prevention. Sci Tot Environ 728: 138882. https://doi.org/10.1016/j.scitotenv.2020.138882

Chakraborty S, Newton AC (2011) Climate change, plant diseases and food security: an overview. Plant Pathol 60(1):2-14. https://oi.org/ 10.1111/j.1365-3059.2010.02411.x

Chakraborty S, Rhee KY (2015) Tuberculosis drug development: history and evolution of the mechanism-based paradigm. Cold Spring Harb. Perspect. Med 5:a021147. https://doi.org/10. 1101/cshperspect.a021147

Chandrashekara C, Kumar R, Bhatt JC, Chandrashekara KN (2012) Supressive soils in plant disease management. In: Singh VK, Singh Y, Singh A (eds) Eco-friendly innovative approaches in plant disease management. International Book Distributors, India, pp 241-256. https://doi.org/10.13140/2.1.5173.7608

Chaparro JM, Sheflin AM, Manter DK, Vivanco JM (2012) Manipulating the soil microbiome to increase soil health and plant fertility. Biol Ferti Soils 48:489-499. https://doi.org/10.1007/ s00374-012-0691-4

Charlop-Powers Z, Pregitzer CC, Lemetre C, Ternei MA, Maniko J, Hover BM, Calle PY, McGuire KL, Garbarino J, Forgione HM, Charlop-Powers S, Brady SF (2016) Urban park soil microbiomes are a rich reservoir of natural product biosynthetic diversity. Proc Natl Acad Sci USA 113(51):14811-14816. https://doi.org/10.1073/ pnas. 1615581113

Chen M, Li X, Yang Q, Chi X, Pan L, Chen N, Yang Z, Wang T, Wang M, Yu S (2014) Dynamic succession of soil bacterial community during continuous cropping of peanut (Arachis hypogaea L.). PLoS One 9:e101355. https://doi.org/10.1371/journal.pone.0101355 
Chen MH, Nelson EB (2008) Seed-colonizing microbes from municipal biosolids compost suppress Pythium ultimum damping-off on different plant species. Phytopathol 98(9):1012-1018. https://doi.org/ 10.1094/PHYTO-98-9-1012

Chen XH, Koumoutsi A, Scholz R, Eisenreich A, Schneider K, Heinemeyer I, Morgenstern B, Voss B, Hess WR, Reva O, Junge $\mathrm{H}$ (2007) Comparative analysis of the complete genome sequence of the plant growth-promoting bacterium Bacillus amyloliquefaciens FZB42. Nat Biotechnol 25(9):1007-1014. https://doi.org/10.1002/ 9781118297674.ch83

Claessen D, Rozen DE, Kuipers OP, Søgaard-Andersen L, van Wezel GP (2014) Bacterial solutions to multicellularity: a tale of biofilms, filaments and fruiting bodies. Nat Rev Microbiol 12:115-124. https:// doi.org/10.1038/nrmicro3178

Clardy J, Fischbach MA, Walsh CT (2006) New antibiotics from bacterial natural products. Nat Biotechnol 24:1541-1550. https://doi.org/ $10.1038 /$ nbt1266

Conn KL, Lazarovits G (1999) Impact of animal manures on verticillium wilt, potato scab, and soil microbial populations. Can J Plant Pathol 21:81-92. https://doi.org/10.1080/07060661.1999.10600089

Cook RJ (2014) Plant Health Management: Pathogen Suppressive Soils. In: Alfen V (ed) Neal K. Academic Press, Encyclopedia of Agriculture and Food Systems, pp 441-455. https://doi.org/10. 1016/B978-0-444-52512-3.00182-0

Cook RJ, Baker KF (1983) The nature and practice of biological control of plant pathogens. The American Phytopathological Society, St. Paul, p 539. https://doi.org/10.1016/0048-4059(84)90064-x

Cook RJ, Thomashow LS, Weller DM, Fujimoto D, Mazzola M, Bangera G, Kim D (1995) Molecular mechanisms of defense by rhizobacteria against root disease. Proc Natl Acad Sci USA 92(10):4197-4201. https://doi.org/10.1073/pnas.92.10.4197

Cordovez V, Carrion VJ, Etalo DW, Mumm R, Zhu H, van Wezel GP et al (2015) Diversity and functions of volatile organic compounds produced by Streptomyces from a disease-suppressive soil. Front Microbiol 6:1081. https://doi.org/10.3389/fmicb.2015.01081

Costa JL, Menge JA, Casal WL (2000) Biological control of Phytophthora root rot of avocado with microorganisms grown in organic mulches. Br J Microbiol 31:239-246

Cotxarrera L, Trillas-Gay MI, Steinberg C, Alabouvette C (2002) Use of sewage sludge compost and Trichoderma asperellum isolates to suppress Fusarium wilt of tomato. Soil Biol Biochem 34:467-476. https://doi.org/10.1016/s0038-0717(01)00205-x

Coventry E, Noble R, Whipps JM (2001) Composting of onion and other vegetable wastes, with particular reference to Allium white rot. Report CSA 4862. Horticulture Research International, Wellesbourne, Warwick, UK, pp 1-95

Cretoiu MS, Korthals GW, Visser JH, van Elsas JD (2013) Chitin amendment increases soil suppressiveness toward plant pathogens and modulates the actinobacterial and oxalobacteraceal communities in an experimental agricultural field. Appl Environ Microbiol 79: 5291-5301. https://doi.org/10.1128/AEM.01361-13

Crowder DW, Jabbour R (2014) Relationships between biodiversity and biological control in agroecosystems: current status and future challenges. Biol Control 75:8-17. https://doi.org/10.1016/j.biocontrol. 2013.10.010

D'Costa VM, Griffith E, Wright GD (2007) Expanding the soil antibiotic resistome: exploring environmental 962 diversity. Curr Opin Microbiol 10:481-489. https://doi.org/10.1016/j.mib.2007.08.009

Davies KG, Rowe JA, Williamson VM (2008) Inter- and intra-specific cuticle variation between amphimictic and parthenogenetic species of root knot nematode (Meloidogyne spp.) as revealed by a bacterial parasite (Pasteuria penetrans). Int J Parasitol 38:851-859. 10 .1016/ j.ijpara.2007.11.007

Davis JR, Huisman OC, Westermann DT, Hafez SL, Everson DO, Sorenson LH, Schneider AT (1996) Effects of green manures on verticillium wilt of potato. Phytopathology 86:444-453. https:// doi.org/10.1094/Phyto-86-444

Dawson TP, Perryman AH, Osborne TM (2016) Modelling impacts of climate change on global food security. Clim Chang 134:429-440. https://doi.org/10.1007/s10584-014-1277-y

De Leij FAAM, Sutton SJ, Whipps JM, Fenlon JS, Lynch JM (1995) Impact of field release of genetically modified Pseudomonas fluorescens on indigenous microbial population of wheat. Appl Environ Microbiol 61:3443-3453. https://doi.org/10.1128/aem.61. 9.3443-3453.1995

Di Cello F, Bevivino L, Chiarini R, Fani R, Paffetti D et al (1997) Biodiversity of a Burkholderia cepacia population isolated from the maize rhizosphere at different plant growth stages. Appl Environ Microbiol 63:4485-4493. https://doi.org/10.1128/aem.63. 11.4485-4493.1997

Dijkstra FA, Morgan JA, Blumenthal D, Follett RF (2010) Water limitation and plant inter-specific competition reduce rhizosphere-induced C decomposition and plant N uptake. Soil Biol Biochem 42:10731082. https://doi.org/10.1016/j.soilbio.2010.02.026

Dong L, Li X, Huang L, Gao Y, Zhong L et al (2014) Lauric acid in crown daisy root exudates potently regulates root-knot nematode chemotaxis and distrupts Mi-flp-18 expression to block infection. J Experi Bot 65:131-114. https://doi.org/10.1093/jxb/ert356

Döring TF, Rosslenbroich D, Giese C, Athmann M, Watson C, Vágó I, Kátai J, Tállai M, Bruns C (2020) Disease suppressive soils vary in resilience to stress. Appl Soil Ecol 149:103482. https://doi.org/10. 1016/j.apsoil.2019.103482

Durán P, Tortella G, Viscardi S, Barra PJ, Carrión VJ, de la Luz MM, José PM (2018) Microbial community composition in take-all suppressive soils. Frontiers in Microbiology 9:2198. https://doi.org/10. 3389/fmicb.2018.02198

Duveiller E, Singh RP, Nicol JM (2007) The challenges of maintaining wheat productivity: pests, diseases, and potential epidemics. Euphytica 157:417-430. https://doi.org/10.1007/ s10681-007-9380-z

El-Masry MH, Khalil AI, Hassouna MS, Ibrahim HAH (2002) In-situ and in vivo suppressive effect of agricultural composts and their water extracts on some phytopathogenic fungi. World J Microbiol Biotech 18:551-558

Expósito RG, de Bruijn I, Postma J, Raaijmakers JM (2017) Current insights into the role of Rhizosphere bacteria in disease suppressive soils. Frontiers in Microbiology 8:1-12. https://doi.org/10.3389/ fmicb.2017.02529

Fernandes JM, Cunha GR, Del Ponte E et al (2004) Modelling fusarium head blight in wheat under climate change using linked processbased models. In: Canty SM, Boring T, Wardwell J, Ward RW (eds) 2nd International Symposium on Fusarium Head Blight; Incorporating the 8th European Fusarium Seminar; 2004, 11-15 December. Orlando, FL, USA, pp 441-444

Fernando WGD, Ramarathnam R, Krishnamoorthy AS, Savchuk SC (2005) Identification and use of potential bacterial organic antifungal volatiles in biocontrol. Soil Biol Biochem 37:955-964. https:// doi.org/10.1016/j.soilbio.2004.10.021

Finney DM, Buyer JS, Kaye JP (2017) Living cover crops have immediate impacts on soil microbial community structure and function. J Soil Water Cons 72:361-373. https://doi.org/10.2489/jswc.72.4.361

Fradkin A, Patrick ZA (1985) Effect of matric potential, pH, temperature, and clay minerals on bacterial colonization of conidia of Cochliobolus sativus and on their survival in soils. Can J Plant Pathol 7:19-27

Fravel DR (2005) Commercialization and implementation of biocontrol. Annu Rev Phytopathol 43:337-359

Freitas LG, Ferraz S, Muchovej JJ (1995) Effectiveness of different isolates of Paecilomyces lilacinus and an isolate of Cylindrocarpon destructans on the control of Meloidogyne 
javanica. Nematropica 25:109-115. http: //journals.fcla.edu/ nematropica/article/view/64128

Gao Z, Karlsson I, Geisen S, Kowalchuk G, Jousset A (2019) Protists: puppet masters of the rhizosphere microbiome. Trends Plant Sci. 24: 165-176. https://doi.org/10.1016/j.tplants.2018.10.011

Garbeva P, Postma J, van Veen JA, van Elsas JD (2006) Effect of above- ground plant species on soil microbial community structure and its impact on suppression of Rhizoctonia solani AG3. Environ Microbiol 8:233-246. https://doi.org/10.1111/j. 1462-2920.2005.00888.x

Garbeva P, van Veen JA, van Elsas JD (2004) Microbial diversity in soil: selection of microbial populations by plant and soil type and implications for disease suppressiveness. Ann Rev Phytopathol 42(1): 243-270. https://doi.org/10.1146/annurev.phyto.42.012604.135455

Gavrish E, Sit CS, Cao S, Kandror O, Spoering A, Peoples A, Ling L, Fetterman A, Hughes D, Bissell A, Torrey H (2014) Lassomycin, a ribosomally synthesized cyclic peptide, kills Mycobacterium tuberculosis by targeting the ATP-dependent protease ClpC1P1P2. Chem Biol. 21(4):509-518. https://doi. org/10.1016/j.chembiol.2014.01.014

Gerlagh M (1968) Introduction of Ophiobolus graminis into new polders and its decline. Neth J Plant Pathol 74:1-97. https://doi.org/10.1007/ bf02019999

Ghorbani R, Wilcockson S, Koocheki A, Leifert C (2008) Soil management for sustainable crop disease control: a review. Environ Chem Lett 6:149-162. https://doi.org/10.1007/s10311-008-0147-0

Giotis C, Theodoropoulou A, Cooper J, Hodgson R, Shotton P, Shiel R, Cretoiu Eyre M, Wilcockson S, Markellou E, Liopa-Tsakalidis A, Volakakis N, Leifert C (2012) Effect of variety choice, resistant rootstocks and chitin soil amendments on soil-borne diseases in soil-based, protected tomato production systems. Eur J Plant Pathol 134:605-617. https://doi.org/10.1007/s10658-012-0041-2

Gooday GW (1990) Physiology of microbial degradation of chitin and chitosan. Biodegradation 1:177-190

Gravato-Nobre MJ, Stroud D, O'Rourke D, Darby C, Hodgkin J (2011) Glycosylation genes expressed in seam cells determine complex surface properties and bacterial adhesion to the cuticle of Caenorhabditis elegans. Genetics 187:141-155. https://doi.org/10. 1534/genetics.110.122002

Green SJ, Inbar E, Michel FC Jr, Hadar Y, Minz D (2006) Succession of bacterial communities during early plant development: transition from seed to root and effect of compost amendment. Appl Environ Microbiol 72:3975-3983. https://doi.org/10.1128/aem.02771-05

Gregory AS, Watts CW, Griffiths BS, Hallett PD, Kuan HL, Whitmore AP (2009) The effect of long-term soil management on the physical and biological resilience of a range of arable and grassland soils in England. Geoderma 153:172-185. https://doi.org/10.1016/j. geoderma.2009.08.002

Griffiths BS, Philippot L (2013) Insights into the resistance and resilience of the soil microbial community. FEMS Microbio Rev 37:112-129. https://doi.org/10.1111/j.1574-6976.2012.00343.x

Grünwald NJ, van Bruggen AHC (2000) Short-term cover crop decomposition in organic and conventional soils: soil microbial and nutrient cycling indicator variables associated with different levels of soil suppressiveness to Pythium aphanidermatum. Eur J Plant Pathol $106: 51-65$

Guerra CA, Heintz-Buschart A, Sikorski J, Chatzinotas A, GuerreroRamírez N, Cesarz S, Beaumelle L, Rillig MC, Maestre FT, Delgado-Baquerizo M, Buscot F (2020). Blind spots in global soil biodiversity and ecosystem function research. Nature communications 11(1):1-13. https://doi.org/10.1038/s41467-020-17688-2

Gustafson K, Roman M, Fenical W (1989) The macrolactins, a novel class of antiviral and cytotoxic macrolides from a deep-sea marine bacterium. J Am Chem Soc 111:7519-7524. https://doi.org/10. 1021/ja00201a036
Haas D, Defago G (2005) Biological control of soil-borne pathogens by fluorescent pseudomonads. Nat Rev Microbiol 3:307-319. https:// doi.org/10.1038/nrmicro1129

Hadar Y, Papadopoulou KK (2012) Suppressive composts: microbial ecology links between abiotic environments and healthy plants. Annu. Rev Phytopathol 50(50):133-153. https://doi.org/10.1146/ annurev-phyto-081211-172914

Haynes RJ (2005) Labile organic matter fractions as central components of the quality of agricultural soils. An overview. Adv Agron 85: 221-268. https://doi.org/10.1016/s0065-2113(04)85005-3

Henis Y, Ghaffar A, Baker R (1978) Integrated control of Rhizoctonia solani damping-off of radish: effect of successive plantings, PCNB and Trichoderma harzianum on pathogen and disease. Phytopathology 68:900-907. https://doi.org/10.1094/Phyto-68-900

Henis Y, Ghaffar A, Baker R (1979) Factors affecting sup- pressiveness to Rhizoctonia solani in soil. Phytopathology 69:1164-1169

Hewavitharana SS, Ruddell D, Mazzola M (2014) Carbon sourcedependent antifungal and nematicidal volatiles derived during anaerobic soil disinfestation. Eur J Plant Pathol 140:39-52. https:// doi.org/10.1007/s10658-014-0442-5

Hjort K, Bergstrom M, Adesina MF, Jansson JK, Smalla K, Sjoling S (2010) Chitinase genes revealed and compared in bacterial isolates, DNA extracts and a metagenomic library from a phytopathogensuppressive soil. FEMS Microbiol Ecol 71:197-207. https://doi org/10.1111/j.1574-6941.2009.00801.x

Hoitink HAJ, Boehm MJ (1999) Biocontrol within the context of soil microbial communities: a substrate-dependent phenomenon. Annu Rev Phytopathol 37:427e446. https://doi.org/10.1146/annurev. phyto.37.1.427

Hoitink HAJ, Boehm MJ, Hadar Y (1993) Mechanisms of suppression of soilborne plant pathogens in compost-amended substrates. In: Hoitink HAJ, Keener HM (eds) Science and engineering of composting: design, environmental, microbiological and utilization aspects. Renaissance, Worthington, pp 601-621

Hoitink HAJ, Krause MS, Han DY (2001) Spectrum and mechanisms of plant disease control with composts. In: Stofella PJ, Kahn BA (eds) Compost Utilization in Horticultural Cropping Systems. Lewis Publishers, Boca Raton, USA, pp 263-274

Hoitink HAJ, Stone AG, Han DY (1997) Suppression of plant disease by composts. Hort Science 32:184-187

Honaganahalli PS, Seiber JN (1996) Health and environmental concerns over the use of fumigants in agriculture: the case of methyl bromide. Amer Chem Soc Pp:1-12

Hornby D (1998) Take-all of cereals: a regional perspective. CAB Int, Wallingford, UK, p 384

Hover BM, Kim SH, Katz M, Charlop-Powers Z, Owen JG, Ternei MA et al (2018) Culture-independent discovery of the malacidins as calcium-dependent antibiotics with activity against multidrugresistant Gram-positive pathogens. Nature Microbiology 3(4):415422. https://doi.org/10.1038/s41564-018-0110-1

Huang XQ, Cui HL, Yang L, Lan T, Zhang JB, Cai ZC (2017) The microbial changes during the biological control of cucumber damping-off disease using biocontrol agents and reductive soil disinfestation. Biocontrol 62:97-109. https://doi.org/10.1007/s10526016-9768-6

Huang XQ, Liu LL, Wen T, Zhang JB, Shen QR, Cai ZC (2016a) Reductive soil disinfestations combined or not with Trichoderma for the treatment of a degraded and Rhizoctonia solani infested greenhouse soil. Sci Horti 206:51-61. https://doi.org/10.1016/j. scienta.2016.04.033

Huang XQ, Liu LL, Wen T, Zhang JB, Wang FH, Cai ZC (2016b) Changes in the soil microbial community after reductive soil disinfestation and cucumber seedling cultivation. Appl Microbiol Biotechnol 100:5581-5593. https://doi.org/10.1007/ s00253-016-7362-6 
Huber DM, Thompson IA (2007) Nitrogen and plant disease. In: Datnoff LE, Elmer WH, Huber DM (eds) Mineral nutrition and plant disease. The American Phytopathological Society, St Paul, pp 31-44

Imperiali N, Dennert F, Schneider J, Laessle T, Velatta C et al (2017) Relationships between root pathogen resistance, abundance and expression of Pseudomonas antimicrobial genes, and soil properties in representative Swiss agricultural soils. Front Plant Sci 8:427

Jack AL, Chapelle E, Siegel K, Edel-Hermann V, Steinberg C, Lemanceau P, Raaijmakers JM (2013) Comparative metagenomics ofdisease suppressive soils. In: Dohrmann AB, Näther A, Tebbe CC (eds) Mining and learning from metagenomes plus workshop on bioinformatic tools. Presented at 2nd Thünen Symposium on Soil Metagenomics, Braunschweig, Germany, pp 48-49

Jambhulkar PP, Sharma M, Lakshman D, Sharma P (2015) Natural mechanisms of soil suppressiveness against diseases caused by Fusarium, Rhizoctonia, Pythium, and Phytophthora. In: Meghvansi MK, Varma A (eds) Organic amendments and soil suppressiveness in plant disease management, Soil Biology, vol 46. Springer International Publishing, Switzerland, pp 95-123. https:// doi.org/10.1007/978-3-319-23075-7_5

Janczura B, Ahern J, Cassells AC (2006) Integrating biological strategies to control disease in intensive agriculture. General and Applied Plant Physiology. In: Acad. M. Popov Institute of Plant Physiology, Bulgarian Academy of Sciences. Sofia, Bulgaria

Jeger MJ, Hide GA, van Den Boogert PHJF, Termorshuizen AJ, van Baarlen P (1996) Pathology and control of soil-borne fungal pathogens of potato. Potato Res 39:437-469. https://doi.org/10.1007/ bf02357949

Jones JB, Jones JP, Stall RE, Zitter TA (1991) Compendium of tomato diseases. The American Phytopathological Society, St Paul, p 100

Jousset A, Rochat L, Scheu S, Bonkowski M, Keel C (2010) Predatorprey chemical warfare determines the expression of biocontrol genes by rhizosphere-associated Pseudomonas fluorescens. Appl Environ Microbiol 76:5263-5268. https://doi.org/10.1128/aem.02941-09

Jousset A, Scheu S, Bonkowski M (2008) Second- ary metabolite production facilitates establishment of rhizobacteria by reducing both protozoan preda- tion and the competitive effects of indigenous bacteria. Functional Ecol 22:714-719

Kaeberlein T, Lewis K, Epstein SS (2002) Isolating 'uncultivable' microorganisms in pure culture in a simulated natural environment. Science 296:1127-1129. https://doi.org/10.1126/science.1070633

Kao CW, Ko WH (1986) Suppression of Pythium splendens in a Hawaiian soil by calcium and microorganisms. Phytopathology 76:215-220

Karlen DL, Varvel GE, Bullock DG, Cruse RM (1994) Crop rotations for the 21 st century. In: Sparks DL (ed) Advances in agronomy. Academic Press, Cambridge, Massachusetts, USA, pp 1-45

Kawase T, Yokokawa S, Saito A, Fuji T, Nikaidou N, Miyashita K, Watanabe T (2006) Comparison of enzymatic and antifungal properties between family 18 and 19 chitinases from S. coelicolor A3(2). Biosci Biotechnol Biochem 70:988-998. https://doi.org/10.1271/ bbb.70.988

Kerry BR (1988) Fungal parasites of cyst nematodes. Agric Ecosyst Environ 24:293-295. https://doi.org/10.1016/0167-8809(88) 90073-4

Kinkel LL, Bakker MG, Schlatter DCA (2011) coevolutionary framework for managing disease-suppressive soils. Annu Rev Phytopathol 49:47-67. https://doi.org/10.1146/annurev-phyto072910-095232

Kirk JL, Beaudettea LA, Hartb M, Moutoglisc P, Klironomosb JN, Lee H, Trevors JT (2004) Methods of studying soil microbial diversity. Journal of Microbiological Methods 58:169- 188. https://doi.org/ 10.1016/j.mimet.2004.04.006

Kluepfel DA, McInnis TM, Zehr EI (1993) Involvement of rootcolonizing bacteria in peach orchard soils suppressive of the nematode Criconemella xenoplax. Phytopathol 83:1240-1245. https://doi.org/10.1094/Phyto-83-1240

Knudsen IMB, Larsen KM, Jensen DF, Hockenhull J (2002) Potential suppressiveness of different field soils to Pythium dampling-off of sugar beet. Appl Soil Ecol 21:119-129

Kobayashi A, Kobayashi YO, Someya N, Ikeda S (2015) Community analysis of root- and tuber-associated bacteria in field-grown potato plants harboring different resistance levels against common scab. Microbes Environ 30:301-309. https:// doi.org/10.1264/jsme2.me15109

Kopecky J, Samkova Z, Sarikhani E, Kyselková M, Omelka M, Kristufek $\mathrm{V}$ et al (2019) Bacterial, archaeal and micro-eukaryotic communities characterize a disease-suppressive or conducive soil and a cultivar resistant or susceptible to common scab. Scientific Reports 9(1):114. https://doi.org/10.1038/s41598-019-51570-6

Kotan R, Dikbas N, Bostan H (2009) Biological control of post-harvest disease caused by Aspergillus flavus on stored lemon fruits. Afr J Biotechnol 8:209-214

Krištůfek V, Diviš J, Dostálková I, Kalčík J (2000) Accumulation of mineral elements in tuber periderm of potato cultivars differing in susceptibility to common scab. Potato Res 43:107-114. https://doi. org/10.1007/bf02357951

Krištůfek V, Diviš J, Omelka M, Kopecký J, Sagová-Marečková M (2015) Site, year and cultivar effects on relationships between periderm nutrient contents and common scab severity. Am J Potato Res 92:473-482. https://doi.org/10.1007/s12230-015-9456-6

Kulkarni-Almeida AA, Brahma MK, Padmanabhan P, Mishra PD, Parab RR, Gaik- wad NV (2011) Fermentation, Isolation, Structure, and antidiabetic activity of NFAT-133 produced by Streptomyces strain PM0324667. AMB Express 21:1-42. https://doi.org/10.1186/21910855-1-42

Kwak YS, Weller DM (2013) Take-all of wheat and natural disease suppression: a review. Plant Pathology Journal 29(2):125-135. https://doi.org/10.5423/PPJ.SI.07.2012.0112

Kyselková M, Kopecký J, Frapolli M, Défago G, Ságová-Marečková M, Grundmann GL, Moënne-Loccoz Y (2009) Comparison of rhizobacterial community composition in soil suppressive or conducive to tobacco black root rot disease. ISME J 3:1127-1138. https:// doi.org/10.1038/ismej.2009.61

Ladner DC, Tchounwou PB, Lawrence GW (2008) Evaluation of the effect of Ecologic on root knot nematode, Meloidogyne incognita, and tomato plant, Lycopersicon esculenum. Int J Environ Res Public Health 5:104-110. https://doi.org/10.3390/ijerph5020104

Lal R (2020) Managing soil quality for humanity and the planet. Front of Agric Sci and Engg 7(3): 251-253. 10.15302/J-FASE-2020329

Larkin RP, Hopkins DL, Martin FN (1996) Suppression of fusarium wilt of watermelon by non-pathogenic Fusarium oxysporum and other microorganisms recovered from a disease suppressive soil. Phytopathol 86:812-819

Latz E, Eisenhauer N, Rall BC, Allan E, Roscher C, Scheu S, Alexandre J (2012) Plant diversity improves protection against soil-borne pathogens by fostering antagonistic bacterial communities. J Ecol 100: 597-604. https://doi.org/10.1111/j.1365-2745.2011.01940.x

Lazarovits G, Hill J, Patterson G, Conn KL, Crump NS (2007) Edaphic soil levels of mineral nutrients, $\mathrm{pH}$, organic matter, and cationic exchange capacity in the geocaulosphere associated with potato common scab. Phytopathol 97:1071-1082. https://doi.org/10.1094/ phyto-97-9-1071

Lee LH, Cheah YK, Sidik SM, Ab Mutalib NS, Tang YT, Lin HP, Hong K (2012) Molecular characterization of Antarctic actinobacteria and screening for antimicrobial metabolite production. World $\mathrm{J}$ Microbiol Biotech 28:2125-2137

Lemanceau P, Alabouvette C (1991) Biological control of fusarium diseases by fluorescent Pseudomonas and non-pathogenic Fusarium. Crop Protect 10:279-286. https://doi.org/10.1016/0261-2194(91) 90006-d 
Lewis K (2012) Antibiotics: Recover the lost art of drug discovery. Nature 485:439-440. https://doi.org/10.1038/485439a

Li B, Ravnskov S, Xie G, Larsen J (2007) Biocontrol of pythium damping-off in cucumber by arbuscular mycorrhiza-associated bacteria from the genus Paenibacillus. BioControl 52:863-875. https:// doi.org/10.1007/s10526-007-9076-2

Li SD (1995) Quantitative assay of Rhizoctonia solani Kuhn AG-1 in soil. Soil Biol Biochem 27:251-256. https://doi.org/10.1016/00380717(94)00189-8

Li X, Zhang Y, Ding C, Jia Z, He Z, Zhang T, Wang X (2015) Declined soil suppressiveness to Fusarium oxysporum by rhizosphere microflora of cotton in soil sickness. Biol Fertil Soils 51(8):935-946. https://doi.org/10.1007/s00374-015-1038-8

Liebman M, Dyck E (1993) Crop rotation and intercropping strategies for weed management. Ecol Appl 3:92-122. https://doi.org/10.2307/ 1941795

Lin BB (2011) Resilience in agriculture through crop diversification: adaptive management for environmental change. BioScience 61: 183-193. https://doi.org/10.1525/bio.2011.61.3.4

Lincke T, Behnken S, Ishida K, Roth M, Hertweck C (2010) Closthioamide: an unprecedented polythioamide antibiotic from the strictly anaerobic bacterium Clostridium cellulolyticum. Angewandte Chemie International Edition 8 49(11):2011-2013. https://doi.org/10.1002/anie.200906114

Ling LL, Schneider T, Peoples AJ, Spoering AL, Engels I, Conlon BP, Mueller A, Schäberle TF, Hughes DE, Epstein S, Jones M, Lazarides L, Steadman VA, Cohen DR, Felix CR, Fetterman KA, Millett WP, Nitti AG, Zullo AM, Lewis K (2015) A new antibiotic kills pathogens without detectable resistance. Nature 517(7535): 455-459. https://doi.org/10.1038/nature14098

Litterick AM, Harrier L, Wallace P, Watson CA, Wood M (2004) The role of uncomposted materials, composts, manures, and compost extracts in reducing pest and disease incidence and severity in sustainable temperate agricultural and horticultural crop production-a review. Crit Rev Plant Sci 23:453-479. https://doi.org/10.1080/ 07352680490886815

Liu B, Gumpertz ML, Hu S, Ristaino JB (2007) Long-term effects of organic and synthetic soil fertility amend- ments on soil microbial communities and the development of southern blight. Soil Biol Biochem 39(9):2302-2316

Liu H, Li J, Cavalhais LC, Percy C, Verma JP, Schenk PM, Singh BK (2020) Evidence for the plant recruitment of beneficial microbes to suppress soil-borne pathogen. New Phytologist. https://doi.org/10. $1101 / 2020.07 .31 .231886$

Löbmann MT, Vetukuri RR, de Zinger L, Alsanius BW, GrenvilleBriggs LJ, Walter AJ (2016) The occurrence of pathogen suppressive soils in Sweden in relation to soil biota, soil properties, and farming practices. Appl Soil Ecol 107:57-65. https://doi.org/10. 1016/j.apsoil.2016.05.011

Lockwood JL (1990) Relation of energy stress to behaviour of soilborne plant pathogens and to disease development. In: Hornby D (ed) Biological control of soilborne plant pathogens. CAB International, Wallingford, UK, pp 197-214

Lorang JM, Liu D, Anderson NA, Schottel JL (1995) Identification of potato scab inducing and suppressive species of Streptomyces. Phytopathology 85:261-268. https://doi.org/10.1094/Phyto-85-261

Loudon AH et al (2014) Interactions between amphibians' symbiotic bacteria cause the production of emergent anti-fungal metabolites. Front Microbiol 5:1-8 3389/fmicb.2014.00441

Mandeel Q, Baker R (1991) Mechanisms involved in biological control of Fusarium wilt of cucumber with strains of nonpathogenic Fusarium oxysporum. Phytopathol 81:462-469. https://doi.org/10. 1094/phyto-81-462

Manici LM, Caputo F, Baruzzi G (2005) Additional experiences to elucidate the microbial component of soil suppressiveness towards strawberry black root rot complex. Ann Appl Biol 146:421-431 /10.1111/j.1744-7348.2005.040051.x

Manucharova NA, Vlasenko AN, Stepanov AL (2007) Temperature as an autoecological factor of chitinolytic microbial complex formation in soils. Biol Bull 34:163-169. https://doi.org/10.1134/ s1062359007020094

Marschner H (1995) Mineral Nutrition of Higher Plants. Academic Press, London

Martin FN, Hancock JG (1986) Association of chemical and biological factors in soils suppressive to Pythium ultimum. Phytopathol 76: 1221-1231. https://doi.org/10.1094/Phyto-76-1221

Mavrodi OV, Walter N, Elateek S, Taylor CG, Okubara PA (2012) Suppression of Rhizoctonia and Pythium root rot of wheat by new strains of Pseudomonas. Biol Control 62:93-102. https://doi.org/10. 1016/j.biocontrol.2012.03.013

Mayer AMS, Rodríguez AD, Berlinck RGS, Fusetani N (2011) Marine compounds with antibacterial, anticoagulant, antifungal, anti-inflammatory, antimalarial, antiprotozoal, antituberculosis, and antiviral activities; is affecting the immune and nervous system, and other miscellaneous mechanisms of action. Comparative Biochemistry and Physiology, Part C. Marine pharmacology in 2007-8 153: 191-222. https://doi.org/10.1016/j.cbpc.2010.08.008

Mazzola M (2007) Manipulation of rhizosphere bacterial communities to induce suppressive soils. J Nematol 39:213-220

Mazzola M, Gu YH (2002) Wheat genotype-specific induction of soil microbial communities suppressive to Rhizoctonia solani AG 5 and AG 8. Phytopathology 92:1300-1307.hhtp:https://doi.org/10.1094/ PHYTO.2002.92.12.1300

McDaniel MD, Tiemann LK, Grandy AS (2014) Does agricultural crop diversity enhance soil microbial biomass and organic matter dynamics? A meta-analysis. Ecol Appl 24:560-570. https://doi.org/10. 1890/13-0616.1

McKellar ME, Nelson EB (2003) Compost-induced suppression of Pythium damping-off is mediated by fatty-acid metabolizing seedcolonizing microbial communities. Appl Environ Microbiol 69: 452-460. https://doi.org/10.1128/aem.69.1.452-460.2003

McLaughlin A, Mineau P (1995) The impact of agricultural practices on biodiversity. Agric Ecosyst Environ 55:201-212. https://doi.org/10. 1016/0167-8809(95)00609-v

Medvecky BA, Ketterings QM, Nelson EB (2007) Relationships among soilborne bean seedling diseases, Lablab purpureus L. and maize stover residue management, bean insect pests, and soil characteristics in Trans Nzoia district, Kenya. Appl Soil Ecol 35:107-119. https://doi.org/10.1016/j.apsoil.2006.05.011

Mendes R, Kruijt M, de Bruijn I, Dekkers E, van der Voort M, Schneider JHM, Piceno YM, DeSantis TZ, Andersen GL, Bakker PAHM, Raaijmakers JM (2011) Deciphering the rhizosphere microbiome for disease suppressive bacteria. Science 332:1097-1100. https:// doi.org/10.1126/science. 1203980

Menzies JD (1959) Occurrence and transfer of a biological factor in soil that suppresses potato scab. Phytopathol 49:648-652

Meyer JR, Linderman RG (1986) Selective influence on populations of rhizosphere or rhizoplane bacteria and actinomycetes by mycorrhizas formed by Glomus fasciculatum. Soil Biol Biochem 18:191196. https://doi.org/10.1016/0038-0717(86)90026-x

Meyer SLF, Huettel RN, Liu XZ, Humber RA, Juba J, Nitao JK (2004) Activity of fungal culture filtrates against soybean cyst nematode and root knot nematode egg hatch and juvenile motility. Nematology 6:23-32. https://doi.org/10.1163/ 156854104323072883

Michel VV, Wang JF, Midmore DJ, Hartman GL (1997) Effects of intercropping and soil amendment with urea and calcium oxide on the incidence of bacterial wilt of tomato and survival of soil-borne Pseudomonas solanacearum in Taiwan. Plant Pathol 46:600-610. https://doi.org/10.1046/j.1365-3059.1997.d01-45.x 
Millner PD, Ringer CE, Maas JL (2004) Suppression of Strawberry Root Disease with Animal Manure Composts. Compost Science and Utilization 12(4):298-307. https://doi.org/10.1080/1065657X. 2004.10702198

Minz D, Ofek M, Hadar Y (2013) Plant rhizosphere microbial communities. In: Rosenberg E, DeLong EF, Lory S, Stackebrandt E, Thompson F (eds) The prokaryotes - prokaryotic communities and ecophysiology. Springer, Berlin, pp 56-84

Momma N, Kobara Y, Uematsu S, Kita N, Shinmura A (2013) Development of biological soil disinfestations in Japan. Appl Microbiol Biotechnol 97:3801-3809. https://doi.org/10.1007/ s00253-013-4826-9

Motisi N, Doré T, Lucas P, Montfort F (2010) Dealing with the variability in biofumigation efficacy through an epidemiological framework. Soil Biol Biochem 42:2044-2057. https://doi.org/10.1016/j.soilbio. 2010.08.016

Mousa WK, Raizada MN (2016) Natural Disease Control in Cereal Grains, 2nd edn. Academic Press, Oxford

Murakami H, Tsushima S, Shishido Y (2000) Soil suppressiveness to clubroot disease of Chinese cabbage caused by Plasmodiophora brassicae. Soil Biol Biochem 32:1637-1642. https://doi.org/10. 1016/s0038-0717(00)00079-1

Nacamulli CB, Dalmastri C, Tabacchioni S, Chiarini L (1997) Perturbation of maize rhizosphere microflora following seed bacterization with Burkholderia cepacia. MCI7. FEMS Microbiol Ecol 23:183-193. https://doi.org/10.1016/s0168-6496(97)00018-4

Neate SM (1994) Soil and crop management practices that affect root diseases of crop plants. CSIRO, East Melbourne, pp 96-106

Neumann G, Romheld V (2007) The release of root exudates as affects by the plant physiological status. In: Pinton R, Varanini Z, Nanniperi P (eds) The rhizosphere: biochemistry and organic substances at the soil-plant interface, second edn. CRC Press, Boca Raton, Florida, USA

Nichols D et al (2010) Use of ichip for high-throughput in situ cultivation of 'uncultivable' microbial species. Appl Environ Microbiol 76: 2445-2450. https://doi.org/10.1128/aem.01754-09

O’Neill J (2016) Tackling Drug-Resistant Infections Globally: Final Report and Recommendations. In: The Review on Antimicrobial Resistance, Welcome Trust \& UK Government

Oerke EC (2006) Crop losses to pests. Journal of Agricultural Science 144:31-43

Oliver MA, Gregory PJ (2015) Soil, food security and human health: a review. Eur J Soil Sci 66(2):257-276. https://doi. org/10.1111/ejss. 12216

Oskay M, Üsame Tamer A, Azeri C (2004) Antibacterial activity of some actinomycetes isolated from farming soils of Turkey. Afr J Biotech 3(9):441-446

Pankhurst CE, McDonald HJ, Hawke BG, Kirkby CA (2002) Effect of tillage and stubble management on chemical and microbiological properties and the development of suppression towards cereal root disease in soils from two sites in NSW, Australia. Soil Biol Biochem 34:833-840. https://doi.org/10.1016/S0038-0717(02)00014-7

Papavizas GC, Ayers WA (1974) Aphanomyces species and their root diseases in pea and sugarbeet. United States Department of Agriculture, Agricultural Research Service. Technical Bulletin:1485

Park YS, Dutta S, Ann M, Raaijmakers JM, Park K (2015) Promotion of plant growth by Pseudomonas fluorescens strain SS101 via novel volatile organic compounds. Biochem Biophys Res Commun 461: 361-365. https://doi.org/10.1016/j.bbrc.2015.04.039

Paulitz T, Baker R (1988) The formation of secondary sporangia by Pythium ultimum: the influence of organic amendments and Pythium nunn. Soil Biol Biochem 20:151-156. https://doi.org/10. 1016/0038-0717(88)90031-4

Pautasso M, Döring TF, Garbelotto M, Pellis L, Jeger MJ (2012) Impacts of climate change on plant diseases - opinions and trends. Eur J Plant Pathol 133:295-313. https://doi.org/10. 1007/s10658-012-9936-1

Payne DJ, Gwynn MN, Holmes DJ, Pompliano DL (2007) Drugs for bad bugs: confronting the challenges of antibacterial discovery. Nature Rev Drug Discov 6:29-40. https://doi.org/10.1038/nrd2201

Peek J, Lilic M, Montiel D, Milshteyn A, Woodworth I, Biggins JB, Ternei MA, Calle PY, Danziger M, Warrier T, Saito K, Braffman N, Fay A, Glickman MS, Darst SA, Campbell EA, Brady SF (2018) Rifamycin congeners kanglemycins are active against rifampicin-resistant bacteria via a distinct mechanism. Nature Communications 9(1):1-15. https://doi.org/10.1038/ s41467-018-06587-2

Penton CR, Gupta VVSR, Tiedje JM, Neate SM, Ophel-Keller K, Gillings M, Harvey P, Pham A, Roget DK (2014) Fungal community structure in disease suppressive soils assessed by $28 \mathrm{~S}$ LSU gene sequencing. PLoS ONE 9(4). https://doi.org/10. 1371/journal.pone.0093893

Peralta AL, Sun Y, McDaniel MD, Lennon JT (2018) Crop rotational diversity increases disease suppressive capacity of soil microbiomes. Ecosphere 9(5). https://doi.org/10.1002/ecs2.2235

Perron GG et al (2015) Functional characterization of bacteria isolated from ancient arctic soil exposes diverse resistance mechanisms to modern antibiotics. PLoS One 10:e0069533. https://doi.org/10. 1371/journal.pone.0069533

Persson L, Larsson-Wikstrom M, Gerhardson B (1999) Assessment of soil suppressiveness to Aphanomyces root rot of pea. Plant Dis 83: 1108-12. https://doi.org/10.1094/PDIS.1999.83.12.1108

Persson L, Olsson S (2000) Abiotic characteristics of soils suppressive to Aphanomyces root rot. Soil Biol Biochem 32:1141-1150. https:// doi.org/10.1016/S0038-0717(00)00030-4

Peters RD, Sturz AV, Carter MR, Sanderson JB (2003) Developing disease-suppressive soils through crop rotation and tillage management practices. Soil Till Res 72:181-192. https://doi.org/10.1016/ s0167-1987(03)00087-4

Pharand B, Carisse O, Benhamou N (2002) Cytological aspects of compost-mediated induced resistance against fusarium crown and root rot in tomato. Phytopathol 92:424-438. https://doi.org/10.1094/ phyto.2002.92.4.424

Picard C, di Cello F, Ventura M, Fani R, Guckert A (2000) Frequency and biodiversity of 2,4-diacetylphloroglucinol producing bacteria isolated from the maize rhizosphere at different stages of plant growth. Appl Environ Microbiol 66:948-955. https://doi.org/10. 1128/aem.66.3.948-955.2000

Postma J, Montanari M, van den Boogert PHJF (2003) Microbial enrichment to enhance the disease suppressive activity. Eur J Soil Biol 39: $157-163$

Postma J, Scheper RWA, Schilder MT (2010) Effect of successive cauliflower plantings and Rhizoctonia solani AG 2-1 inoculations on disease suppressiveness of a suppressive and a conducive soil. Soil Biol Biochem 42:804-812. https://doi.org/10. 1016/j.soilbio.2010.01.017

Postma J, Schilder MT (2015) Enhancement of soil suppressiveness against Rhizoctonia solani in sugar beet by organic amendments. Appl Soil Ecol 94:72-79. https://doi.org/10.1016/j. apsoil.2015.05.002

Raaijmakers JM, Mazolli M (2012) Diversity and natural functions of antibiotics produced by beneficial and plant pathogenic bacteria. Annu Rev Phytopathol 50:403-424. https://doi.org/10.1146/ annurev-phyto-081211-172908

Raaijmakers JM, Paulitz TC, Steinberg C, Alabouvette C, MoënneLoccoz Y (2009) The rhizosphere: a playground and battlefield for soil borne pathogens and beneficial microorganisms. Plant Soil 321: 341-361. https://doi.org/10.1007/s11104-008-9568-6

Radwan MA, Farrag SAA, Abu-Elamayem MM, Ahmed NS (2012) Extraction, characterization, and nematicidal activity of chitin and 
chitosan derived from shrimp shell waste. Biol Fertil Soils 48:463468. https://doi.org/10.1007/s00374-011-0632-7

Ramaswamy S, Musser JM (1998) Molecular genetic basis of antimicrobial agent resistance in Mycobacterium tuberculosis: 1998 update. Tuber Lung Dis 79:3-29

Ramette A, Moënne-Loccoz Y, Dé fago G (2006) Genetic diversity and biocontrol potential of fluorescent pseudomonads producing phloroglucinols and hydro- gen cyanide from Swiss soils naturally suppressive or conducive to Thielaviopsis basicola mediated black root rot of tobacco. FEMS Microbiol Ecol 55:369-381. https://doi. org/10.1111/j.1574-6941.2005.00052.x

Reeleder RD (2003) Fungal plant pathogens and soil biodiversity. Can J Soil Sci 83:331-336. https://doi.org/10.4141/s01-068

Reuveni R, Raviv M, Krasnovsky A, Freiman L, Medina S, Bar A, Orion D (2002) Compost induces protection against Fusarium oxysporum in sweet basil. Crop Protection 21:583-587. https://doi.org/10.1016/ s0261-2194(01)00149-1

Rosenzweig N, Tiedje JM, Quensen JF, Meng Q, Hao JJ (2012) Microbial communities associated with potato common scabsuppressive soil determined by pyrosequencing analyses. Plant Dis 96:718-725. https://doi.org/10.1094/PDIS-07-11-0571

Rosenzweig WD, Stotzky G (1979) Influence of environmental factors on antagonism of fungi by bacteria in soil: clay minerals and $\mathrm{pH}$. Appl Environ Microbiol 38:1120-1126

Rousk J, Bååth E, Brookes PC, Lauber CL, Lozupone C et al (2010) Soil bacterial and fungal communities across a $\mathrm{pH}$ gradient in an arable soil. ISME J 4:1340-1351. https://doi.org/10.1038/ismej.2010.58

Rouxel F, Alabouvette C, Louvet J (1977) Recherches sur la r'esistance des sols aux maladies. II. Incidence de traitements thermiques sur la r'esistance microbiologique d'un sol ‘a la Fusariose vasculaire du melon. Ann Phytopathol 9:183-192

Rudrappa T, Kirk J, Czymmek PW, Paré PW, Bais HP (2008) Rootsecreted malic acid recruits beneficial soil bacteria. Plant Physiol 148:1547-1556. https://doi.org/10.2307/40066285

Sarathchandra SU, Watson RN, Cox NR, di Menna ME, Brown JA, Burch G, Neville FJ (1996) Effects of chitin amendment of soil on microorganisms, nematodes, and growth of white clover (Trifolium repens L.) and perennial ryegrass (Lolium perenne L.). Biol Fertil Soils 22:221-226. https://doi.org/10.1007/BF00382516

Scheuerell S, Sullivan D, Walter M (2005) Suppression of Seedling Damping-Off Caused by Pythium ultimum , P. irregulare, and Rhizoctonia solani in Container Media Amended with a Diverse Range of Pacific Northwest Compost Sources. Phytopathology 95: 306-315 https://doi.org/10.1094/PHYTO-95-0306

Schlatter D, Kinkel L, Thomashow L, Weller D, Paulitz T (2017) Disease suppressive soils: New insights from the soil microbiome. Phytopathol 107(11):1284-1297. https://doi.org/10.1094/PHYTO03-17-0111-RVW

Schmidt R, Cordovez V, de Boer W, Raaijmakers J, Garbeva P (2015) Volatile affairs in microbial interactions. ISME J. https://doi.org/10. 1038/ismej.2015.42

Scholthof KBG (2007) The disease triangle: pathogens, the environment and society. Nat Rev Microbiol 5(2):152-156. https://doi.org/10. 1038/nrmicro1596

Schulz S, Dickschat JS (2007) Bacterial volatiles: the smell of small organisms. Nat Prod Rep 24:814-842. https://doi.org/10.1039/ b507392h

Secilia J, Bagyaraj DJ (1987) Bacteria and actinomycetes associated with pot cultures of vesicular arbuscular mycorrhizas. Can J Microbiol 33:1069-1073

Serra-Wittling C, Houot S, Alabouvette C (1996) Increased soil suppressiveness to Fusarium wilt of flax after addition of municipal solid waste compost. Soil Biol Biochem 28:1207-1214. https://doi.org/ 10.1016/0038-0717(96)00126-5

Shi SJ, Richardson AE, O'Callaghan M, DeAngelis KM, Jones EE, Stewart A, Firestone MK, Condron LM (2011) Effects of selected root exudate components on soil bacterial communities. FEMS Microbiol Ecol 77:600-610. https://doi.org/10.1111/j.1574-6941. 2011.01150.x

Shi W et al (2019) The occurrence of potato common scab correlates with the community composition and function of the geocaulosphere soil microbiome. Microbiome 7:1-18. https://doi.org/10.1186/s40168019-0629-2

Shiomi Y, Nishiyama M, Onizuka T, Marumoto T (1999) Comparison of bacterial community structures in the rhizoplane of tomato plants grownin soils suppressive and conducive toward bacterial wilt. Appl Environ Microbiol 65:3996-4001

Siegel-Hertz K, Edel-Hermann V, Chapelle E, Terrat S, Raaijmakers JM, Steinberg C (2018) Comparative microbiome analysis of a Fusarium wilt suppressive soil and a Fusarium wilt conducive soil from the Chateaurenard region. Front in Microbiol 9:568. https://doi.org/10. 3389/fmicb.2018.00568

Smolinska U (2000) Survival of Sclerotium cepivorum sclerotia and Fusarium oxysporum chlamydospores in soil amended with cruciferous residues. J Phytopathol Phytopathologische Zeitschrift 148: 343-349

Smukler SM, Sánchez-Moreno S, Fonte SJ, Ferris H, Klonsky K, O'Geen AT, Scow KM, Steenwerth KL, Jackson LE (2010) Biodiversity and multiple ecosystem functions in an organic farmscape. Agric Ecosyst Environ 139:80-97. https://doi.org/ 10.1016/j.agee.2010.07.004

Stirling GR (2014) Biological Control of Plant-Parasitic Nematodes, second edn. CAB International, Wallingford

Stone AG, Scheuerell SJ, Darby HM (2004) Suppression of soil borne diseases in field agricultural systems: organic matter management, cover cropping and other cultural practices. In: Magdoff F, Weil R (eds.) Soil Organic Matter in Sustainable Agriculture, CRC Press, Boca Raton, pp 131-177. hort.oregonstate.edu/files/Faculty Staff/ On_Campus/stonea/1294_C05.pdf

Stotzky G, Martin RT (1963) Soil mineralogy in relation to the spread of Fusarium wilt of banana in Central America. Plant Soil 18:317-337

Stotzky G (1966a) Influence of clay minerals on microorganisms. Part II: Effect of various clay species, homoionic clays, and other particles on bacteria. Can J Microbiol 12:831-848

Stotzky G (1966b) Influence of clay minerals on microorganisms. Part III: Effect of particle size, cation exchange capacity, and sur- face area on bacteria. Can J Microbiol 12:1235-1246

Stotzky G (1986) Influence of soil mineral colloids on metabolic processes, growth, adhesion, and ecology of microbes and viruses. In: Huang PM, Schnitzer M (eds) Interactions of Soil Minerals with Natural Organics and Microbes. Soil Science Society of America, Madison, pp 305-428

Stotzky G, Post AH (1967) Soil mineralogy as a possible factor in geographic distribution of Histoplasma capsulatum. Can J Microbiol 13:1-7. https://doi.org/10.1139/m67-001

Strauss SL, Greenhut RF, McClean AE, Kluepfel DA (2017) Effect of anaerobic soil disinfestation on the bacterial community and key soilborne phytopathogenic agents under walnut tree-crop nursery conditions. Plant Soil 415:493. https://doi.org/10.1007/s11104016-3126-4

Strieker M, Marahiel MA (2009) The structural diversity of acidic lipopeptide antibiotics. Chembiochem 10:607-616. /10.1002/ cbic. 200800546

Stutz E, Kahr G, DeÂ fago G (1989) Clays involved in suppression of tobacco black root rot by a strain of Pseudomonas fuorescens. Soil Biol Biochem 21:361-366. https://doi.org/10.1016/0038-0717(89) 90144-2

Stutz EW, Defago G, Kern H (1986) Naturally occurring fluorescent pseudomonads involved in suppression of black root rot of tobacco. Phytopathology 76:181-185. https://doi.org/10.1094/Phyto-76-181 
Sullivan P (2001) Sustainable management of soil-borne plant diseases. ATTRA, USDA's Rural Business Cooperative Service https:// www.attra.org

Sun Y, Zhou T, Wang Y, Chen J, He X et al (2006) Effect of intercropping on disease management and yield of chilli pepper and maize. Acta Horticulturae Sinica 33:995-1000

Taffner J et al (2018) What is the role of Archaea in plants? New insights from the vegetation of alpine bogs. mSphere 3:e00122-e00118. https://doi.org/10.1128/mSphere.00122-18

Tamm L, Thürig B, Bruns C, Fuchs JG, Köpke U, Laustela M, Leifert C, Mahlberg N, Nietlispach B, Schmidt C, Weber F, Fließbach A (2010) Soil type, management history, and soil amendments influence the development of soil-borne (Rhizoctonia solani, Pythium ultimum) and air-borne (Phytophthora infestans, Hyaloperonospora parasitica) diseases. Eur J Plant Pathol 127: 465-481. https://doi.org/10.1007/s10658-010-9612-2

Termorshuizen AJ, van Rijn E, van der Gaag DJ, Alabouvette C, Chen Y, Lagerlof J, Malandrakis AA, Paplomatas EJ, Ramert B, Ryckeboer J, Steinberg C, Zmora-Nahum S (2006) Suppressiveness of 18 composts against 7 pathosystems: variability in pathogen response. Soil Biol Biochem 38(8):2461-2477. https://doi.org/10.1016/j.soilbio. 2006.03.002

Thompson SE, Levin S, Rodriguez-Iturbe I (2014) Rainfall and temperatures changes have confounding impacts on Phytophthora cinnamomi occurrence risk in the southwestern USA under climate change scenarios. Glob Change Biol 20:1299-1312. https://doi.org/ $10.1111 / \mathrm{gcb} .12463$

Tiemann LK, Grandy AS, Atkinson EE, Marin- Spiotta E, McDaniel MD (2015) Crop rotational diversity enhances belowground communities and functions in an agroecosystem. Ecol Lett 18:761-771. https://doi.org/10.1111/ele.12453

Tilman D, Cassman KG, Matson PA, Naylor R, Polasky S (2002) Agricultural sustainability and intensive production practices. Nature 418:671-677. https://doi.org/10.1038/nature01014

Tilston EL, Pitt D, Groenhof AC (2002) Composted recycled organic matter suppresses soil-borne diseases of field crops. New Phytologist 154:731-740. https://doi.org/10.1046/j.1469-8137. 2002.00411.x

Timmer RD, Korthals GW, Molendijk LPG (2003) Groebenmesters. Van teelttechniek tot ziekten en plagen. Brochure PPO 316:59

Toyota K, Kimura M (1993) Colonization of chlamydospores of Fusarium oxysporum f. sp. raphani by soil bacteria and their effects on germination. Soil Biol Biochem 25(193):197. https://doi.org/10. 1016/0038-0717(93)90026-8

Uroz S et al (2016) Specific impacts of beech and Norway spruce on the structure and diversity of the rhizosphere and soil microbial communities. Sci Rep 6:1-11. https://doi.org/10.1038/srep27756

van Agtmaal M, Straathof AL, Termorshuizen A, Lievens B, Hoffland E, de Boer W (2018) Volatile-mediated suppression of plant pathogens is related to soil properties and microbial community composition. Soil Biol Biochem 117:164-174. https://doi.org/10.1016/j.soilbio. 2017.11.015

van Bruggen AHC, Semenov AM (2000) In search of biological indicators for soil health and disease suppression. Appl Soil Ecol 15:1324. https://doi.org/10.1016/s0929-1393(00)00068-8

van Bruggen AHC, Sharma K, Kaku E, Karfopoulos S, Zelenev VV, Blok WJ (2015) Soil health indicators and Fusarium wilt suppression in organically and conventionally managed greenhouse soils. Appl Soil Ecol 86:192-201. https://doi.org/10. 1016/j.apsoil.2014.10.014

van Dijk K, Nelson EB (2000) Fatty acid competition as a mechanism by which Enterobacter cloacae suppresses Pythium ultimum sporangium germination and damping-off. Appl Environ Microbiol 66: 5340-5347. https://doi.org/10.1128/aem.66.12.5340-5347.2000

van Overbeek LS, Senechkin IV, van Bruggen AHC (2012) Variation in microbial responses and Rhizoctonia solani AG2-2IIIB growth in soil under different organic amendment regimes. Can J Plant Pathol 34:268-276. https://doi.org/10.1080/07060661.2012.679622

Van Wezel GP, McKenzie NL, Nodwell JR (2009) Chapter 5. Applying the genetics of secondary metabolism in model actinomycetes to the discovery of new antibiotics. Methods Enzymol. 458: 117-141. 10.1016/S0076- 6879(09)04805-8

Venter ZS, Jacobs K, Hawkins HJ (2016) The impact of crop rotation on soil microbial diversity: a meta-analysis. Pedobiologia 59:215-223. https://doi.org/10.1016/j.pedobi.2016.04.001

Wall DH, Bardgett RD, Behan-Pelletier V, Herrick JE, Jones TH, Ritz K, Six J, Strong DR, van der Putten WH (2012) Soil Ecology and Ecosystem Services. Oxford University Press, Oxford

Wang Z, Wang C, Li F, Li Z, Chen M, Wang Y, Qiao X, Zhang H (2013) Fumigant activity of volatiles from Streptomyces alboflavus TD-1 against Fusarium moniliforme Sheldon. J Microbiol 51:477-483. https://doi.org/10.1007/s12275-013-2586-y

Watve MG, Tickoo R, Jog MM, Bhole BD (2001) How many antibiotics are produced by the genus Streptomyces? Arch. Microbiol 176:386390. https://doi.org/10.1007/s002030100345

Weibelzahl-Fulton E, Dickson DW, Whitty EB (1996) Suppression of Meloidogyne incognita and M. Javanica by Pasteuria penetrans in field soil. J Nematol 28:43-49

Weller DM, Landa BB, Mavrodi OV, Schroeder KL, De La Fuente L et al (2006) Role of 2,4-Diacetylphloroglucinol-Producing Fluorescent Pseudomonas spp. in the Defense of Plant Roots. Plant Biol 9:420. https://doi.org/10.1055/s-2006-924473

Weller DM, Raaijmakers JM, McSpadden Gardener BB, Thomashow LS (2002) Microbial populations responsible for specific soil suppressiveness. Annu Rev Phytopathol 40:309-348. https://doi.org/10. 1146/annurev.phyto.40.030402.110010

Westerlund FV, Campbell RN, Grogan RG, Duniway JM (1978) Soil factors affecting the reproduction and survival of Olpidium brassicae and its transmission of big vein agent to lettuce. Phytopathol 68:927-935

Wieland G, Neumann R, Backhaus H (2001) Variation of microbial communities in soil, rhizosphere and rhizoplane in response to crop species, soil type and crop development. Appl Environ Microbiol 67:5849-5854. https://doi.org/10.1128/AEM.67.12. $5849-5854.2001$

Wilson MC et al (2014) An environmental bacterial taxon with a large and distinct metabolic repertoire. Nature 506:58-62. https://doi.org/ 10.1038/nature 12959

Wiseman BM, Neate SM, Keller KO, Smith SE (1996) Suppression of Rhizoctoniasolani anastomosis group 8 in Australia and its biological nature. Soil Biol Biochem 28:727-732

Wu T, Chellemi DO, Graham JH, Martin KJ, Rosskopf EN (2008) Comparison of soil bacterial communities under diverse agricultural land management and crop production practices. Microb Ecol 55(2): 293-310. https://doi.org/10.2307/25153463

Xu L, Ravnskov S, Larsen J, Nilsson RH, Nicolaisen M (2012a) Soil fungal community structure along a soil health gradient in pea fields examined using deep amplicon sequencing. Soil Biol Biochem 46: 26-32. https://doi.org/10.1016/j.soilbio.2011.11.010

Xu L, Ravnskov S, Larson J, Nicolaisen M (2012b) Linking fungal communities in roots, rhizosphere, and soil to the health status of Pisum sativum. FEMS Microbiol Ecol 82:736-745. https://doi.org/10. 1111/j.1574-6941.2012.01445.x

Yang M, Zhang Y, Qi L, Mei X, Liao J et al (2014) Plant-Plant-Microbe Mechanisms Involved in Soil-Borne Disease Suppression on a Maize and Pepper Intercropping System. PLOS ONE 9(12): e115052. https://doi.org/10.1371/journal.pone.0115052

Yin C, Hulbert SH, Schroeder KL, Mavrodi O, Mavrodi D, Dhingra A, Schillinger WF, Paulitz TC (2013) Role of bacterial communities in the natural suppression of Rhizoctonia solani bare patch disease of wheat (Triticum aestivum L.). Appl Environ Microbiol 79:74287438. https://doi.org/10.1128/aem.01610-13 
Yogev A, Raviv M, Hadar Y, Cohen R, Wolf S, Gil L, Katan J (2010) Induced resistance as a putative component of compost suppressiveness. Biol Control 54(1):46-51. https://doi.org/10.1016/j.biocontrol. 2010.03.004

Zahn G, Wagai R, Yonemura S (2016) The effects of amoebal bacterivory on carbon and nitrogen dynamics depend on temperature and soil structure interactions. Soil Biol Biochem 94:133-137. https://doi.org/10.1016/j.soilbio.2015.11.021

Zak DR, Holmes WE, White DC, Peacock AD, Tilman D (2003) Plant diversity, soil microbial communities and ecosystem function: are there any links? Ecol 84(8):2042-2050. https:// doi.org/10.1890/02-0433

Zumla A et al (2015) The WHO 2014 Global tuberculosis report-further to go. Lancet Glob Health 3:e10-e12. https://doi.org/10.1016/S2214

Publisher's note Springer Nature remains neutral with regard to jurisdictional claims in published maps and institutional affiliations. 